Paolo Nimis · Svetlana G. Tesalina · Paolo Omenetto

Paola Tartarotti · Catherine Lerouge

\title{
Phyllosilicate minerals in the hydrothermal mafic-ultramafic-hosted massive-sulfide deposit of Ivanovka (southern Urals): comparison with modern ocean seafloor analogues
}

Received: 15 August 2003/ Accepted: 9 February 2004 / Published online: 17 March 2004

(C) Springer-Verlag 2004

\begin{abstract}
We have studied textural relationships and compositions of phyllosilicate minerals in the maficultramafic-hosted massive-sulfide deposit of Ivanovka (Main Uralian Fault Zone, southern Urals). The main hydrothermal phyllosilicate minerals are Mg-rich chlorite, variably ferroan talc, $(\mathrm{Mg}, \mathrm{Si})$-rich and $(\mathrm{Ca}, \mathrm{Na}$, $\mathrm{K}$ )-poor saponite (stevensite), and serpentine. These minerals occur both as alteration products after mafic volcanics and ultramafic protoliths and, except serpentine, as hydrothermal vein and seafloor mound-like precipitates associated with variable amounts of $(\mathrm{Ca}$, $\mathrm{Mg}, \mathrm{Fe})$-carbonates, quartz and $\mathrm{Fe}$ and $\mathrm{Cu}(\mathrm{Co}, \mathrm{Ni})$ sulfides. Brecciated mafic lithologies underwent pervasive chloritization, while interlayered gabbro sills underwent partial alteration to chlorite + illite \pm actinolite \pm saponite \pm talc-bearing assemblages and later localized deeper alteration to chlorite \pm saponite. Ultramafic and mixed ultramafic-mafic breccias were altered to talc-rich rocks with variable amounts of chlorite, carbonate and quartz. Chloritization, locally accompanied by formation of disseminated sulfides,
\end{abstract}

Editorial responsibility: J. Hoefs

P. Nimis $(\bowtie) \cdot$ S. G. Tesalina $\cdot$ P. Omenetto

Dipartimento di Mineralogia e Petrologia,

Università degli Studi di Padova, C.so Garibaldi 37,

35137 Padova, Italy

E-mail: paolo.nimis@unipd.it

Tel.: + 39-049-8272022

Fax: + 39-049-8272010

P. Nimis $\cdot$ P. Omenetto

Kroseven Services S.A.S., Padova, Italy

S. G. Tesalina

Institute of Mineralogy, Uralian Division,

Russian Academy of Sciences, 456301 Miass, Russia

P. Tartarotti

Dipartimento di Scienze della Terra,

Università di Milano, Milano, Italy

C. Lerouge

BRGM, B.P. 6009, 45060 Orléans Cedex 2, France required a high contribution of Mg-rich seawater to the hydrothermal fluid, which could be achieved in a highly permeable, breccia-dominated seafloor. More evolved hydrothermal fluids produced addition of silica, carbonates and further sulfides, and led to local development of saponite after chlorite and widespread replacement of serpentine by talc. The Ivanovka deposit shows many similarities with active and fossil hydrothermal sites on some modern oceanic spreading centers characterized by highly permeable upflow zones. However, given the arc signature of the ore host rocks, the most probable setting for the observed alteration-mineralization patterns is in an early-arc or forearc seafloorsubseafloor environment, characterized by the presence of abundant mafic-ultramafic breccias of tectonic and/ or sedimentary origin.

\section{Introduction}

Phyllosilicate minerals are a major constituent of lowgrade metamorphic and hydrothermally altered maficultramafic rocks. Their association with massive sulfide deposits is well known both in modern ocean seafloor hydrothermal sites and in their ancient counterparts, and analogies between modern and ancient examples have been pointed out by several workers (e.g. Costa et al. 1983; Kranidiotis and MacLean 1987; Evans and Guggenheim 1988; Zierenberg et al. 1995). The nature and compositions of the phyllosilicate minerals can be used to discriminate between various metamorphic and hydrothermal environments (e.g. Shikazono and Kawahata 1987; Laird 1988), to gain an insight into hydrothermal processes at or near the seafloor (Aggarwal and Nesbitt 1984; Evans and Guggenheim 1988), as well as to estimate physical and chemical conditions extant during rock-fluid interaction and hydrothermal precipitation (e.g. Cathelineau and Nieva 1985; Cathelineau 1988; Zierenberg and Shanks 1988). Formation of phyllosilicate minerals during hydrothermal alteration is 
often associated with significant removal or uptake of metals and silica. These processes contribute to the compositional evolution of the hydrothermal fluids and produce geochemical and mineralogical zoning within hydrothermal recharge and upflow zones (Alt 1995).

The results presented herewith form part of a comprehensive study of mineralizations and ore-host rock relationships in mafic-ultramafic-hosted, massive sulfide deposits in southern Urals. In this paper we describe phyllosilicate mineralogy in a little known deposit from the Main Uralian Fault Zone, located near the village of Ivanovka (Fig. 1). We will show that this deposit constitutes an example of fossil hydrothermal body in which the original seafloor-subseafloor hydrothermal mineral assemblages and textures have been extraordinarily well preserved. The compositions and paragenetic relations of the Ivanovka phyllosilicates will be discussed through comparisons with those reported for hydrothermal deposits on modern seafloor settings.

\section{Geological outline}

The Urals are a linear orogenic belt that resulted from the Late-Palaeozoic collision of the East European Platform with a Siberian-Kazakhian plate assemblage and interposed oceanic and island-arc terranes. The Main Uralian Fault Zone (hereafter MUFZ), a 2 to 10$\mathrm{km}$-wide (locally up to $25 \mathrm{~km}$ ), east dipping fault system,

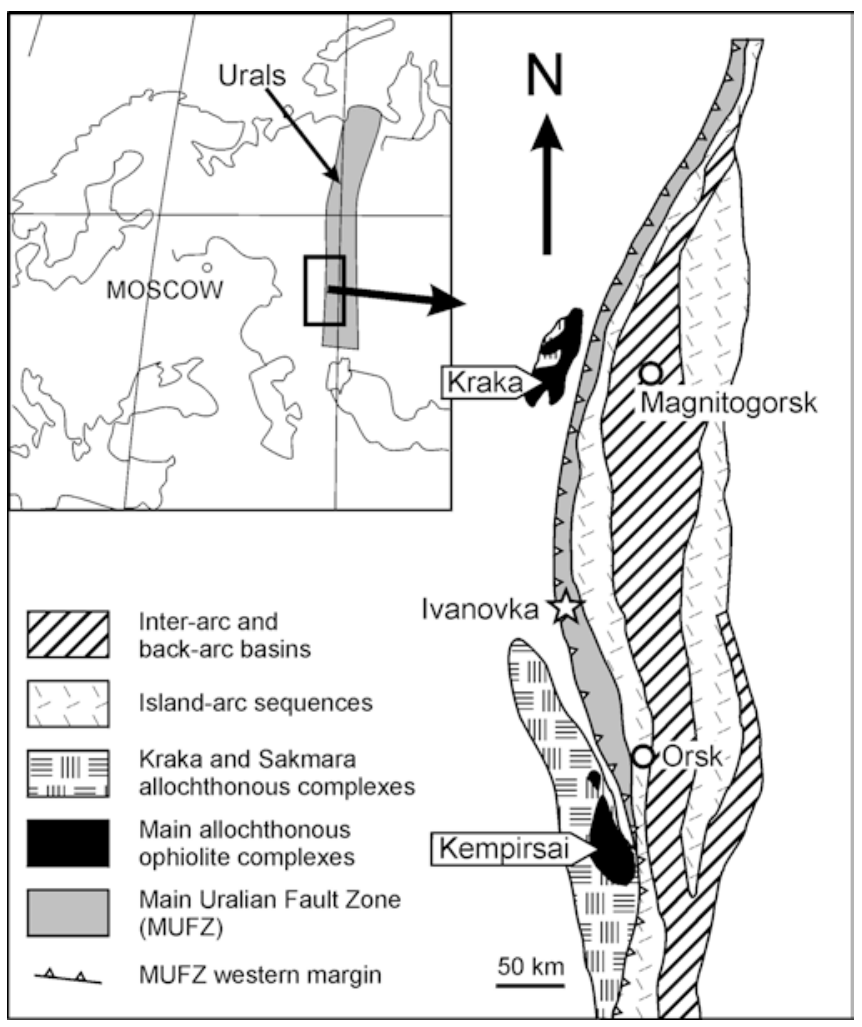

Fig. 1 Geological sketch-map of the southern Urals, with location of the Ivanovka ore field marks the main suture that can be traced continuously along the Uralide Orogen (e.g. Puchkov 1997) (Fig. 1). The MUFZ is interpreted as the major damage zone that developed between an accretionary wedge to the west and a forearc basement to the east during Late Devonian arc-continent collision (Brown and Spadea 1999). It comprises a mélange of dismembered mafic-ultramafic sheets made of serpentinites, gabbros, basalts, dolerites, mingled with Mid-Ordovician to Mid-Devonian sedimentary rocks (e.g. Maslov et al. 1993; Seravkin et al. 2001). The sedimentary units include olistostromes which carry olistolites of volcanic and intrusive igneous rocks and, sometimes, seafloor hydrothermal mounds of carbonatic and carbonaticsiliceous composition.

In the southern Urals, important massive sulfide deposits belonging to the Cyprus, Besshi, Baimak (Kuroko), and Uralian types are associated with MidPalaeozoic ophiolitic and island-arc volcanic sequences (Prokin and Buslaev 1999; Herrington et al. 2002). Mafic-ultramafic-hosted massive sulfide occurrences along the southern MUFZ (i.e. Ivanovka, Dergamish, and Ishkinino deposits) are represented by small-sized, at present subeconomic, $\mathrm{Cu}(\mathrm{Co}, \mathrm{Au})$ deposits (Zaykov et al. 2000; Herrington et al. 2002). Sulfide mineralization in these deposits is traditionally thought to occur near or at the contact between variously metasomatized serpentinitic and basaltic units (e.g. Ismagilov 1962; Buchkovskiy 1970; Zakharov and Zakharova 1975; Zaykov et al. 2000). This idea may not be completely correct. Based on petrographic and geochemical analyses (see Mineral textures and hydrothermal parageneses), we believe that many ore-bearing rocks that have been described in the literature as "metasomatized serpentinite" (or "aposerpentinity" in the Russian lit.) actually include a mélange of hydrothermally altered mafic and ultramafic lithologies of both crustal and mantle derivation.

\section{The Ivanovka deposit}

At Ivanovka, basalts of post-Silurian, possibly EarlyMid Devonian age (Seravkin et al. 2001) rest on an extensively metasomatized sequence of mafic-ultramafic rock breccias cross-cut by several pre-metasomatic gabbroic sills, decimetric to metric in thickness (Figs. 2 and 3). The mixed mafic-ultramafic rock sequence hosts the sulfide mineralization and lies on a serpentinite unit. Metamorphism, probably related at least in part to oceanic hydrothermal alteration, is mostly represented by serpentinization of former harzburgites and dunites, and by albite + chlorite + epidote + quartz greenschist-facies metamorphism of mafic rocks. The latter are well exposed on an escarpment along the Yangyz River, a few hundred meters north-east of the ore deposit.

The sulfide mineralization comprises massive, disseminated and stockwork ores which consist of dominant tabular, lamellar and granular pyrrhotite, with or 

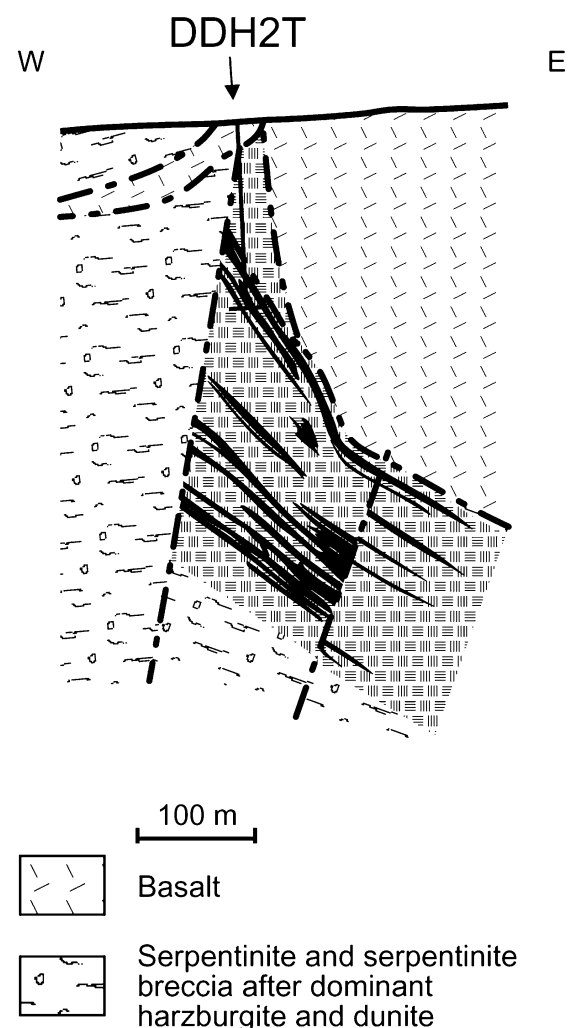

Serpentinite and serpentinite breccia after dominant harzburgite and dunite Hydrothermally-altered mafic-ultramafic rocks, with sulphides

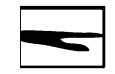

Main massive sulphide levels

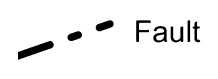

\section{$\perp$ Drillhole}

Fig. 2 Geological section of the Ivanovka deposit (simplified after Buchkovskiy 1970)

without pyrite and chalcopyrite. Gangue minerals include $\mathrm{Mg}$-rich chlorite, variably ferroan talc, $\mathrm{Mg}$-rich saponite, quartz, and $(\mathrm{Ca}, \mathrm{Mg}, \mathrm{Fe}$ )-carbonates (mostly dolomite). The uppermost ore level is characterized by peculiar, open-latticework aggregates of lamellar pyrrhotite associated with chalcopyrite-cubanite intergrowths and interstitial Mg-rich saponite, Mg-rich chlorite, or carbonates (Nimis et al. 2003) (Fig. 4). Accessory hydrothermal ore minerals are cobaltite, sphalerite, Co-rich pyrite, Co-rich pentlandite, Nirich glaucodot as well as traces of native gold, native bismuth and pilsenite (Bi-telluride) (Tesalina et al. 2001). In addition, the sulfides often include abundant (up to $3 \%$ ) relict chromite crystals and fragments derived from the host rocks (Tesalina et al. 2003).

The metal grades and the abundance of accessory sulfides appear to be controlled by the composition of the host rocks, which are altered to talc- or chlorite-rich metasomatic assemblages consisting of variable pro- portions of talc, $(\mathrm{Ca}, \mathrm{Mg}, \mathrm{Fe})$-carbonates, chlorite, saponite, and quartz (Zakharov and Zakharova 1975; and in-house unpublished data). The sulfide-rich levels are mainly $(75 \%)$ restricted to chlorite-rich rocks after mafic protoliths, where also higher $\mathrm{Cu}(\mathrm{Co}, \mathrm{As}, \mathrm{Au})$ occur (ca. $1 \% \mathrm{Cu}$ ). Relatively high $\mathrm{Ni}$ contents $(0.1-$ $0.2 \%)$, with low $\mathrm{Cu}(\mathrm{Co}, \mathrm{As}, \mathrm{Au})$, are mostly found in talc-rich, ultramafic-hosted mineralizations. Significant $\mathrm{Au}$ contents (up to $5.4 \mathrm{ppm}$ ) are found near the top of the ore-bearing sequence within pyrite + chalcopyrite + pyrrhotite-bearing assemblages.

The Ivanovka deposit differs from sulfide deposits within the Uralian back-arc and island-arc terranes by its extremely poor $\mathrm{Zn}$ grades $\left(<\right.$ to $<<0.1 \%$ ) and $\mathrm{Co}^{-}$ As-Ni-Bi (Au) specialization (Tesalina et al. 2001). The aggregates of lamellar pyrrhotite that occur at the top of the deposits strictly resemble those found in some modern seafloor hydrothermal mounds (Peter and Scott 1988; Goodfellow and Franklin 1993; Turner et al. 1993; Zierenberg et al. 1993), suggesting formation near or at the seafloor. However, the presence of stockwork mineralizations, the widespread association of sulfides with alteration minerals, the presence of inclusions of relict chromite, as well as local replacement of alteration phyllosilicates by sulfides, indicate that the Ivanovka ores dominantly formed in the subsurface by cementation, replacement and veining.

\section{Sample materials and analytical methods}

Sample materials were mainly taken from a drill-core (DDH2T) obtained during the 1998 drilling campaign by Bashkirgeologia (Ufa). The drill-core is representative of the shallowest portions of the Ivanovka deposit and crosscuts several mineralized and barren levels. The uppermost portion is almost totally barren and represented by tectonic slices which were thrust over the main sulfide-bearing sequence. A detailed description of the drill-core stratigraphy is given in Fig. 3. Additional samples were taken from outcrops in the deposit's nearest surroundings. In the following, notations of the type Iv36.0 will be used to indicate samples from the Ivanovka drill-core DDH2T taken from depths in meters as indicated by the numbers.

Polished thin sections of representative rock types, including both mineralized and barren lithologies, were prepared for optical and scanning-electron microscopy and electron microprobe analysis. In some cases, identification of mineral phases was aided by qualitative X-ray powder diffraction (XRD) of whole-rocks and separated mineral grains. In a few cases, XRD analysis was repeated after saturation with ethylene glycol and after in-situ heating at $350{ }^{\circ} \mathrm{C}$ for $1.5 \mathrm{~h}$.

Chemical analyses of minerals (Tables 2 through 6) were carried out at the CNR-IGG-Dipartimento di Mineralogia e Petrologia, University of Padua, using a CAMECA "CAMEBAX" electron microprobe equipped with four vertical WDS spectrometers, operating at an accelerating voltage of $15 \mathrm{kV}$, beam current of $15 \mathrm{nA}$, counting time of $10 \mathrm{~s}$ for peak and $10 \mathrm{~s}$ for background, using a $1-\mu \mathrm{m}$ beam. Some saponite analyses were replicated using a lower beam current $(10 \mathrm{nA})$ and a defocused beam $(5 \mu \mathrm{m})$ to minimize interlayer cation loss. Natural and synthetic minerals (wollastonite for $\mathrm{Ca}$ and $\mathrm{Si}$, albite for $\mathrm{Na}$, orthoclase for $\mathrm{K}$ ) and pure oxides (for $\mathrm{Al}, \mathrm{Cr}, \mathrm{Fe}$, and $\mathrm{MnTi}$ ) were used as standards. The CAMECA-PAP program was used to convert X-ray counts into weight percent oxides. Reproducibility of analyses was found to be within $\pm 1-2 \%$ relative for major and within $\pm 2-5 \%$ relative for minor oxides. 


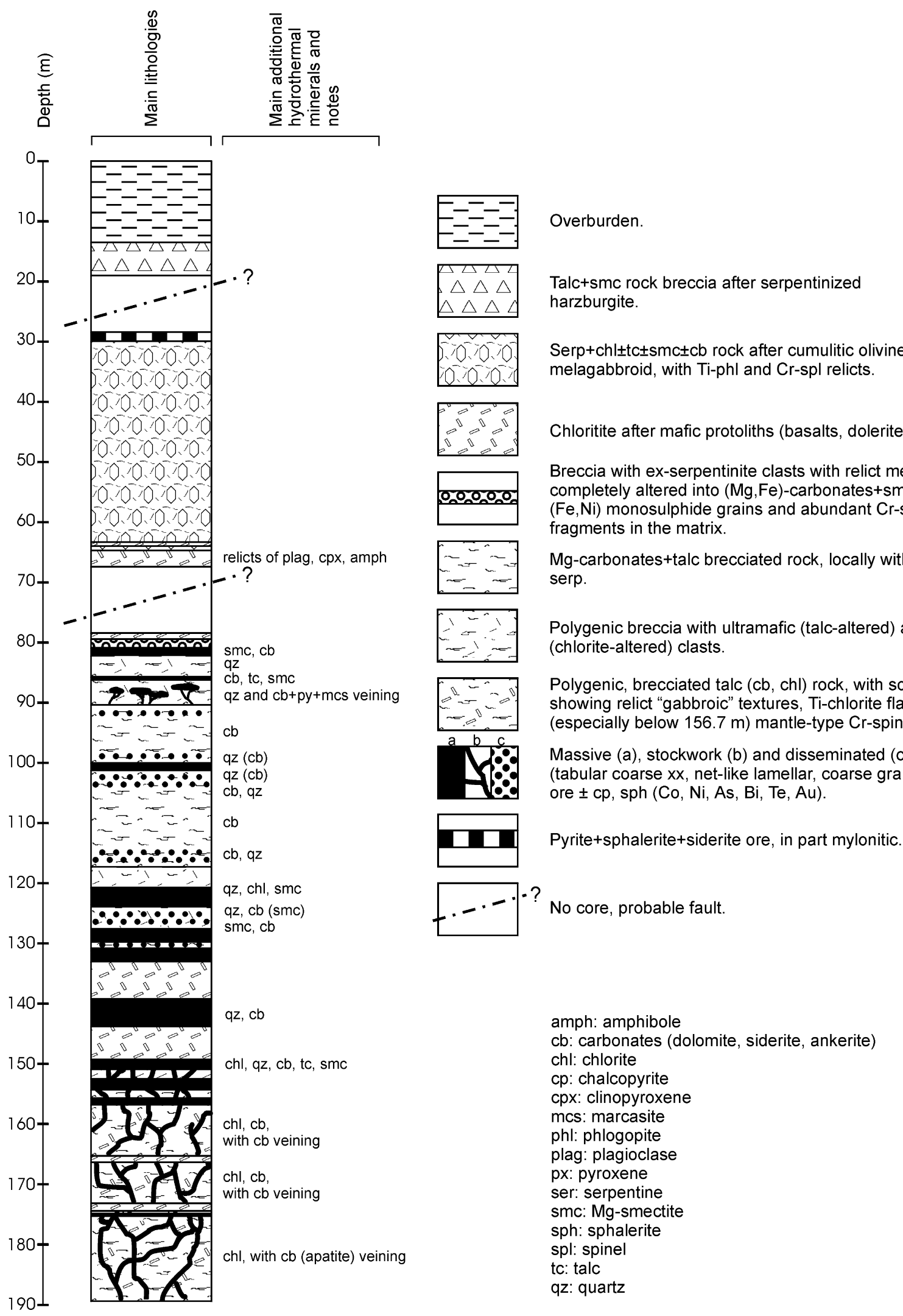

Scanning electron microscope (SEM) analyses were carried out at the Dipartimento di Mineralogia e Petrologia, University of Padua, using a CamScan MX2500 microscope, equipped with a tungsten cathode and a four-quadrant solid-state BSE detector.

Qualitative chemical microanalysis were carried out using an EDAX system with a "Sapphire" detector (LEAP + Si(Li) crystal). The analytical conditions were: $20 \mathrm{kV}$ accelerating voltage, $\sim 160 \mu \mathrm{A}$ filament emission, and $35 \mathrm{~mm}$ working distance. 
Fig. 3 Description of Ivanovka drill-core DDH2T (modified after Tesalina et al. 2003)

Six whole-rock samples representative of different alteration patterns and a talc concentrate were analyzed for oxygen isotopic composition by laser fluorination, following the procedure of Fouillac and Girard (1996). Isotopic data are reported in $\delta$ units relative to V-SMOW. Reproducibility of $\delta$ values was found to be within $\pm 0.3 \%$

\section{Mineral textures and hydrothermal parageneses}

The samples studied include extensively to completely altered mafic and ultramafic rocks, and associated orebearing hydrothermalites. Phyllosilicates occur in alteromorphs after olivine, pyroxenes, plagioclase and, probably, glass, and as major or minor constituents of veins and of interstitial matrix in the sulfide ores. Where relicts of the original pre-alteration textures or minerals are preserved, the alteration sequences listed in Table 1 and described below can be observed.

Fig. 4 Back-scattered electron image showing a peculiar pyrrhotite $(P o)+\mathrm{Mg}$-saponite $(\mathrm{Sap}) \pm \mathrm{Mg}$-chlorite $(\mathrm{Chl})$ association in a sample from the top of the Ivanovka orebody (Iv80.5). A network of coarse $(<1 \mathrm{~mm})$ pyrrhotite lamellas in association with $\mathrm{Mg}$ saponite, siderite $(S i d)$ and chalcopyrite $(C p)$ is visible in the upper portion of the main picture. In the enlargement a concentric structure is shown, that is composed of an inner network of fine $(<10 \mu \mathrm{m})$ lamellar pyrrhotite $+\mathrm{Mg}$-saponite, an intermediate pyrrhotite + Mg-saponite + Mg-chlorite shell and an outer pyrite $(P y)$ rim
Sequences (1) through (4) describe the alteration of olivine-rich (ca. $50 \mathrm{vol} \%$ ) gabbroic rocks, which were tectonically superimposed on the main sulfide orebody and constitute a major portion of the shallow Ivanovka drill-core (32.0-64.7 $\mathrm{m}$ depth; Fig. 3). These rocks exhibit heteradcumulate texture, with completely altered euhedral olivine and poikilitic pyroxene crystals, completely altered interstitial matrix (probably representing former intercumulus plagioclase \pm pyroxene), and flakes of partially altered titanian phlogopite (Fig. 5a, b). In these rocks, serpentine of late hydrothermal derivation often occurs as fine-grained mixtures with $\mathrm{Mg}$-rich saponite or Mg-rich chlorite. The strong alteration does not allow accurate classification of the protoliths and the general term melagabbroid will be used here according to standard criteria (Le Maitre et al. 1989).

Sequence (5) characterizes fine- to ultrafine-grained, almost monomineralic chloritites which probably developed after aphyric mafic protoliths. These chloritites, often occurring in brecciated form (former hyaloclastites?), are often associated with abundant pyrrhotite + chalcopyrite \pm cobaltite (Fig. 5c, d). A later chlorite, characterized by anomalous "blue" interference colors and associated with Mg-rich saponite, may locally replace an earlier chlorite characterized by anomalous "olive-brown" interference colors.

Sequences (6) through (8) describe the progressive alteration of medium- to coarse-grained mafic rocks. Some of the medium-grained examples retain clear relicts of a magmatic intersertal texture, which suggests their derivation from highly phyric mafic protoliths such as subvolcanic dolerites or pillow cores. In such

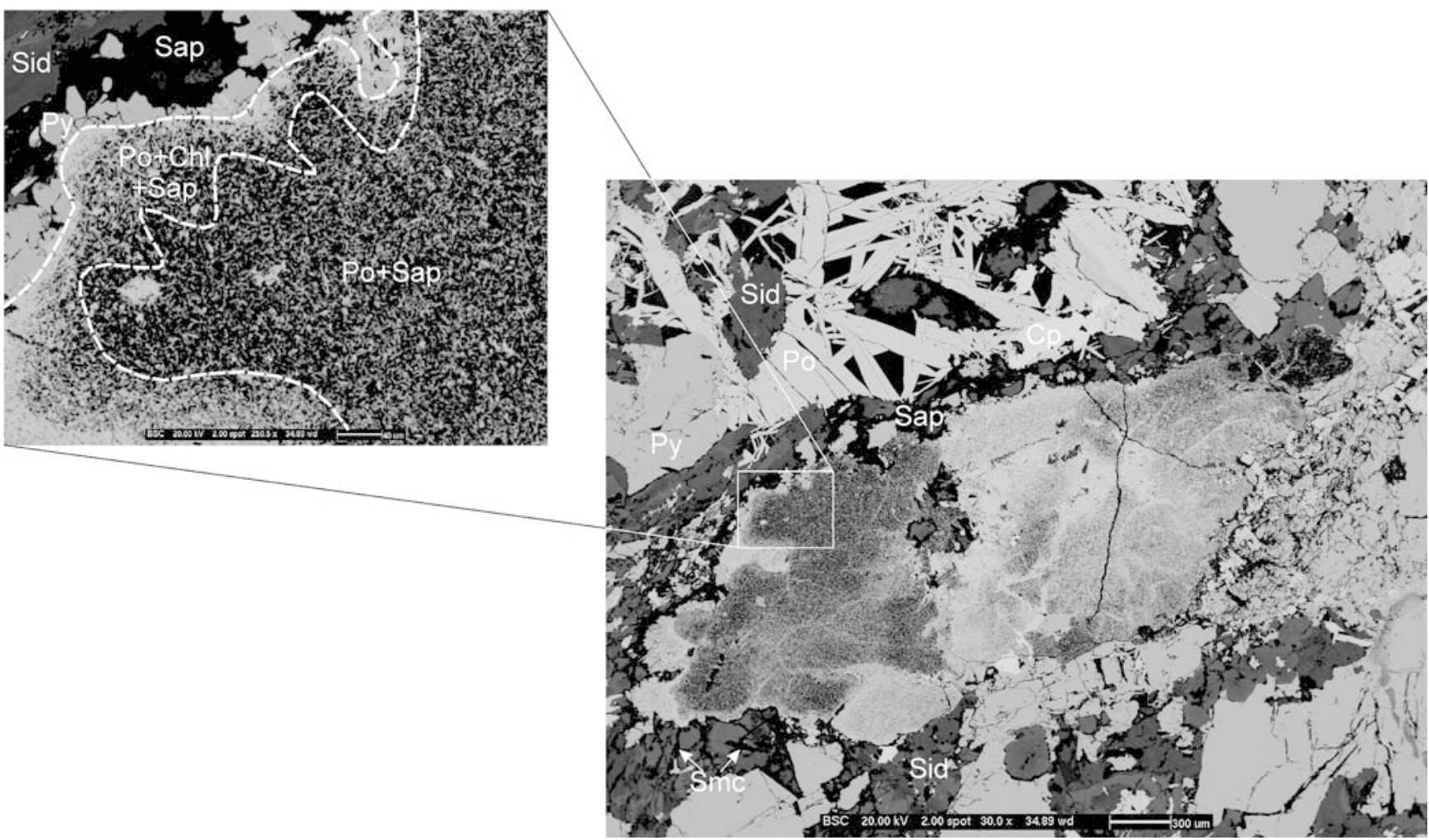


Table 1 Recognized hydrothermal alteration sequences in the Ivanovka samples

Olivine-rich melagabbroids

(1) olivine $\rightarrow$ talc + magnetite $\rightarrow$ serpentine \pm Mg-saponite

Iv30.0-64.7

\pm magnetite $(\rightarrow$ talc $)(\rightarrow$ dolomite $)$

(2) pyroxene $\rightarrow$ Mg-saponite \pm chlorite \pm magnetite $\rightarrow$ serpentine

$\pm \mathrm{Mg}$-saponite \pm magnetite

(3) plagioclase $\rightarrow$ chlorite + serpentine \pm Mg-saponite

(4) titanian phlogopite $\rightarrow$ (chlorite) $\rightarrow$ (serpentine)

Fine-grained chloritites (after basalts l.s.)

(5) basalt $(\rightarrow$ chlorite-smectite ? + rutile) $\rightarrow$ chlorite + rutile

$(\rightarrow \mathrm{Mg}$-saponite \pm dolomite-ankerite \pm chlorite \pm quartz)

Gabbros and highly phyric basalts l.s.

(6) pyroxene $\rightarrow$ chlorite \pm actinolite \pm Mg-saponite $(\rightarrow$ talc) ( $\rightarrow$ chlorite) Iv64.0; Iv65.2; Iv78.5; Iv174.7

(7) ${ }^{\text {a }}$ amphibole $\rightarrow$ actinolite $\rightarrow$ chlorite \pm Mg-saponite \pm talc

(8) plagioclase $\rightarrow$ chlorite \pm illite \pm Mg-saponite $(\rightarrow$ chlorite-smectite ?

\pm illite or Mg-saponite \pm dolomite-ankerite \pm chlorite \pm quartz)

Serpentinites (after peridotitic melting residua and cumulates)

(9) olivine \pm orthopyroxene $\rightarrow$ serpentine ${ }^{b}$

$(\rightarrow$ talc \pm Mg-saponite or talc \pm carbonate \pm quartz $)$

Iv14.0; Iv82.0-117.0; Iv155.0-177.3

Notations in parentheses indicate alteration assemblages that in some samples were apparently not developed or preserved

Assemblages in italic were deduced from textural relations and alteration patterns (i.e. no relicts preserved)

chloritites, "blue" and "olive-brown" chlorites tend to occupy texturally distinct sites, which can reasonably be related to former clinopyroxene and plagioclase crystals, respectively. Many of these medium-grained chloritites, which often occur in brecciated form, are host to abundant disseminated lamellar and massive granular pyrrhotite. Non-brecciated gabbroic levels, which probably represent sills intruded in the breccia sequence, exhibit less extensive alteration, with preserved relicts of minerals belonging to the original magmatic parageneses (e.g. slightly Na-enriched plagioclase, $\mathrm{Ab}_{43-70}$ ) or produced during incipient alteration processes (Fig. 5e). In these rocks the original magmatic amphibole and pyroxene have been completely transformed into actinolite and chlorite \pm actinolite $\pm \mathrm{Mg}$-saponite, respectively, during an early stage of alteration. Local further alteration to talc or chlorite of mafic minerals was accompanied by replacement of plagioclase by illite and/or chlorite $\pm \mathrm{Mg}$-saponite in patches and along cleavage planes.

Sequence (9) has produced mesh- and ribbon-textured serpentinites after original peridotites (harzburgites, dunites and minor lherzolites). The habit of the relict chromian spinel allowed us to distinguish two groups of protoliths (cf. Tesalina et al. 2003). The first group includes residues after mantle partial melting, which are characterized by holly-leaf or amoeboid spinels. The second group includes magmatic protoliths of mantle and possibly lower-crust derivation, which are characterized by euhedral or subhedral spinels. The serpentinites are abundant in the deposit's surroundings and often occur in the form of breccias of tectonic and, in part, possibly sedimentary origin. They are never associated with massive sulfides and their origin was probably related to early oceanic alteration. Later
${ }^{\text {a }}$ Sequence represented only in gabbros

${ }^{\mathrm{b}}$ Probably related to early oceanic alteration

hydrothermal alteration is testified by substitution of serpentine by talc $\pm \mathrm{Mg}$-rich saponite in some serpentinite samples.

Fig. 5 Representative modes of occurrence of phyllosilicate minerals in samples from Ivanovka drill-core DDH2T. a Alteration patterns in an olivine-rich melagabbroic rock (\#Iv44.0). A euhedral olivine crystal is altered to talc + magnetite and further altered to serpentine along fractures and rims. Matrix is a fine intergrowth of Mg-chlorite + serpentine after interstitial plagioclase \pm pyroxene (?). The dashed line contours a chlorite + serpentine + magnetite alteromorph after pyroxene (?). Flakes of largely unaltered titanian phlogopite $(P h l)$ are present. Plane polarized transmitted light. b Alteration patterns in an olivine-rich melagabbroic rock showing pervasive serpentinization and olivine cores replaced by $\mathrm{Mg}$ saponite (\#Iv36.0). A crystal of largely unaltered titanian phlogopite $(P h l)$ is shown in the upper right corner. Crossed polars, transmitted light. c, d Fissure cutting through massive pyrrhotite $(P o)$. The fissure is filled by a microbreccia of fragments of finegrained chloritite ( $C h l)$, partially altered to Mg-saponite ( Sap), and of pyrrhotite ore, set in a matrix made of ( $\mathrm{Fe}, \mathrm{Mn})$-bearing dolomite ( $D o l), \mathrm{Mg}$-saponite, small euhedral cobaltite crystals and small chromite crystals and fragments (\#Iv132.7). Plane polarized (c) and crossed polars ( d) transmitted light. e Partial alteration in a gabbro sill (\#Iv78.5). During an early stage of alteration, pyroxene was totally replaced by chlorite $\pm \mathrm{Mg}$-saponite ( $C h l)$, while plagioclase ( Plag) underwent slight Na-enrichment $\left(\mathrm{Ab}_{43-70}\right)$. Subsequently, talc $(T c)$ and illite + chlorite $(I C)$ partly replaced the chloritized pyroxene and the plagioclase, respectively. Crossed polars, transmitted light. f Mantle spinel peridotite showing complete alteration of serpentinized (?) olivine to talc ( $T c$ ) and an unaltered amoeboid chromite crystal ( Chr) (\#Iv161.3). The rock shown is a clast in a polygenic, talc \pm chlorite \pm carbonate-altered mafic-ultramafic breccia with carbonate cement and stockwork sulfide mineralization. Crossed polars, transmitted light. g Breccia altered to talc $(T c)$ and carbonate $(C b)$, showing a probable pseudomorph after Ti-rich phlogopite, now replaced by Ti-rich and Ti-poor chlorite ( $T i-C h l$ ) (\#Iv176.2). Crossed polars, transmitted light. h Late, composite dolomite ( $D o l)$-quartz ( $Q z)$-chlorite $(C h l)$ vein cutting through massive pyrrhotite (\#Iv141.8). Plane polarized transmitted light 
In addition, several talc \pm carbonate \pm chlorite \pm quartz rocks, usually with inherited brecciated appearance and often associated with disseminated, stringer or massive sulfide ores, occur in the Ivanovka drill-core at depths from $82.0 \mathrm{~m}$ down to at least $177.3 \mathrm{~m}$ (Fig. 3). In many instances, these rocks do not show unambiguous textural relicts, therefore the nature of their protoliths often remains undetermined. However, the occurrence, sometimes within the same thin section, of amoeboid chromite crystals (Fig. 5f) and of titanian chlorite pseudomorphs after probable titanian phlogopite resembling that found in the shallower melagabbroids (Fig. 5g), the occasional presence of ghost mesh and coarse granular "gabbroic" (?) textures, as well as whole-rock geochemical data (Fig. 6), suggest that some and possibly all of the talc-altered breccias were originally composed of a mélange of disrupted crustal and mantle rocks.

Virtually unaltered accessory minerals in the above described rocks include rutile and ilmenite (probably derived at least in part from alteration of silicates), apatite, zircon, xenotime and monazite in mafic rocks, up to mm-sized chromite in ultramafic rocks and submillimetric chromite in melagabbroids.

Phyllosilicate-bearing epigenetic hydrothermal veins and veinlets crosscut all the above lithologies and include the mineral assemblages chlorite \pm quartz \pm carbonate
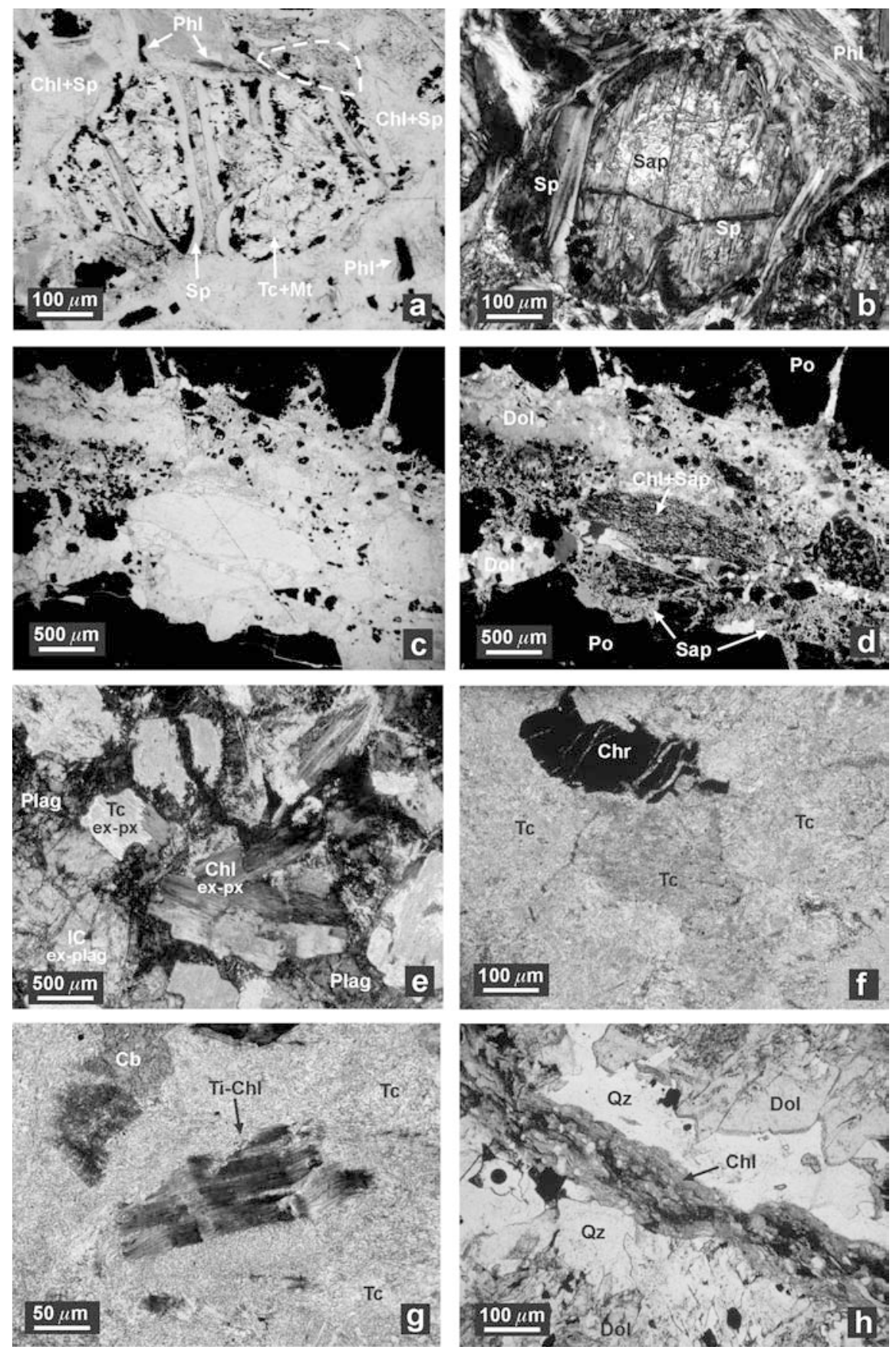


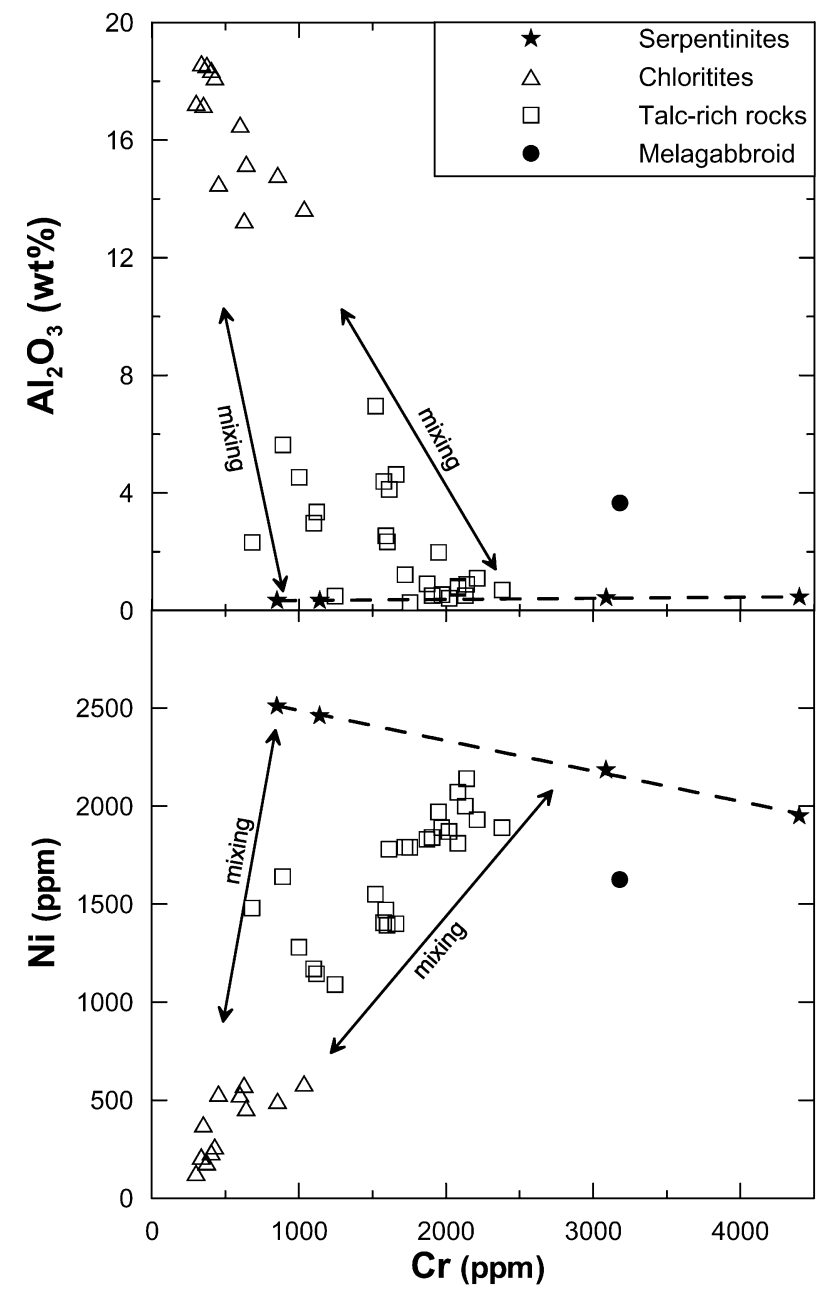

Fig. $6 \mathrm{Cr}$ vs. $\mathrm{Ni}$ and $\mathrm{Cr}$ vs. $\mathrm{Al}$ relations in talc-rich rocks and chloritites from Ivanovka drill-core DDH2T and serpentinites from surrounding areas. Talc-rich rocks plot between chloritites after mafic protoliths and serpentinites after mantle peridotites, suggesting a mixture of ultramafic and mafic components. Data are from Nimis et al. (in prep.). Linear fit through the serpentinite data is shown as dashed line

(Fig. 5h), chlorite + talc, and talc + Mg-saponite \pm carbonate. Late carbonate-rich (dolomite-ankerite-siderite $\pm \mathrm{Mg}$-saponite $\pm \mathrm{Mg}$-rich chlorite \pm talc) veins are widespread. Matrix phyllosilicates in sulfide-rich samples are part of the following mineral assemblages: Mg-saponite $\pm \mathrm{Mg}$-rich chlorite, $\mathrm{Mg}$-saponite + carbonates, talc \pm Mg-rich chlorite \pm carbonates.

\section{Mineral chemistry}

\section{Chlorite}

Five main groups can be distinguished among the studied chlorites on the basis of their textural relations and chemical compositions. Group $A$ includes chlorites occurring as main component of chloritites after mafic protoliths (Fig. 5c, d, e). Group B includes chlorites associated with quartz and carbonate, forming veins and filling voids in pyrrhotite ores (Fig. 5h). Group C includes chlorites associated with talc in pyrrhotite ores and talc + chlorite rocks (Fig. 5g). Group D includes chlorites in weakly altered gabbros (Fig. 5e). Group $E$ is represented by a single chlorite included in a chromite grain, which is set in a matrix made of talc and Group-C chlorite. Representative chlorite analyses are reported in Table 2 .

For all the studied chlorites the sum of nominally octahedral cations per 28 oxygens (i.e. $20 \mathrm{O}+16 \mathrm{OH}$ ) is close to the ideal trioctahedral value of 12 $($ range $=11.72-12.02 ;$ median $=11.88)$, the apparent octahedral vacancies are uniformly low irrespective of tetrahedral Si vs. Al substitution (Fig. 7), and the sum of interlayer cations $(\mathrm{Na}+\mathrm{K}+2 \mathrm{Ca})$ never exceeds 0.18 $($ median $=0.02)$. This ensures us against significant contamination of the electron microprobe analyses by associated talc, saponite, albite or quartz (cf. Jiang et al. 1994). The relative proportions of chlorite to swelling components were estimated to $86-101 \%$ (median $=94 \%$; Table 2) following the procedure proposed by W. Wise (1987; personal communication to Bettison and Schiffman 1988; cf. also Bettison-Varga et al. 1991; Bevins et al. 1991). However, powder XRD spectra of two chloritite samples (Iv134.9 and Iv144.7) before and after glycolation or heating to $350{ }^{\circ} \mathrm{C}$ for $1.5 \mathrm{~h}$ revealed no detectable interlayered swelling component.

All chlorites bar one are classified as clinochlore (i.e. Mg-rich trioctahedral chlorite). Although obsolete, the $\mathrm{Fe} /(\mathrm{Fe}+\mathrm{Mg})$ vs. Si classification scheme of Hey (1954) can facilitate comparison with other published data (Fig. 8). Group- $A$ chlorites mostly plot in Hey's pycnochlorite field. They show an inverse $\mathrm{Fe} /(\mathrm{Fe}+\mathrm{Mg})$ vs. Si correlation [and the complementary $\mathrm{Fe} /(\mathrm{Fe}+\mathrm{Mg})$ vs. ${ }^{[4]} \mathrm{Al}$ correlation; Fig. 9a, c] and an overall trend from $(\mathrm{Mg}, \mathrm{Si})$-rich penninite towards Fe-rich ripidolite. The lowest $\mathrm{Fe} /(\mathrm{Fe}+\mathrm{Mg})$ and highest $\mathrm{Si}$ was found in a chlorite replacing plagioclase in a weakly altered gabbro (Iv174.7). Some of the late "blue" chlorites replacing "olive-brown" chlorite in some chloritites after mafic protoliths (e.g. sample Iv132.7; Table 2) are particularly enriched in iron and straddle the pycnochlorite-ripidolite boundary. Group-B vein and ore-associated chlorites occurring together with quartz and carbonate partly overlap those of Group-A, but are variably enriched in silica and range in composition from $(\mathrm{Mg}, \mathrm{Si})$-rich pycnochlorite to diabantite. Group-C chlorites occurring together with talc in both sulfide-bearing and barren rocks and Group-D chlorites in weakly altered gabbros are characterized by low iron contents $[\mathrm{Fe} /$ $(\mathrm{Fe}+\mathrm{Mg}) \leq 0.18]$ and high, although variable, Si contents. These chlorites straddle Hey's clinochlore-penninite boundary. In particular, Group-D chlorites show the highest calculated proportions of swelling components $(12-14 \%)$, which may be largely ascribed to minor contamination by fine intergrown Mg-saponite. Group-E inclusion in chromite falls in Hey's clinochlore field and shows the lowest $\mathrm{Fe} /(\mathrm{Fe}+\mathrm{Mg})$ ratio (0.04) and the highest $\mathrm{Cr}$ content $\left(\mathrm{Cr}_{2} \mathrm{O}_{3}=3.3 \mathrm{wt} \%\right)$. The anomalous 


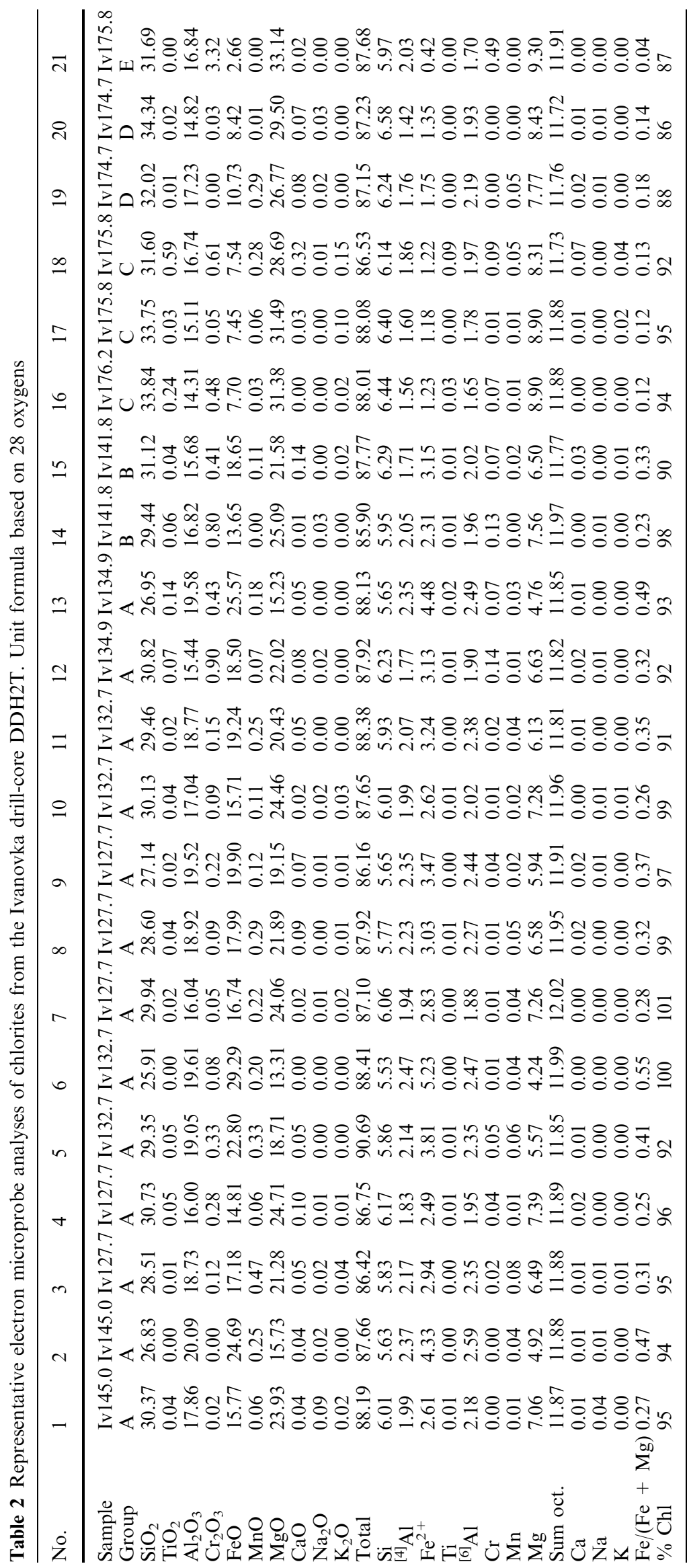

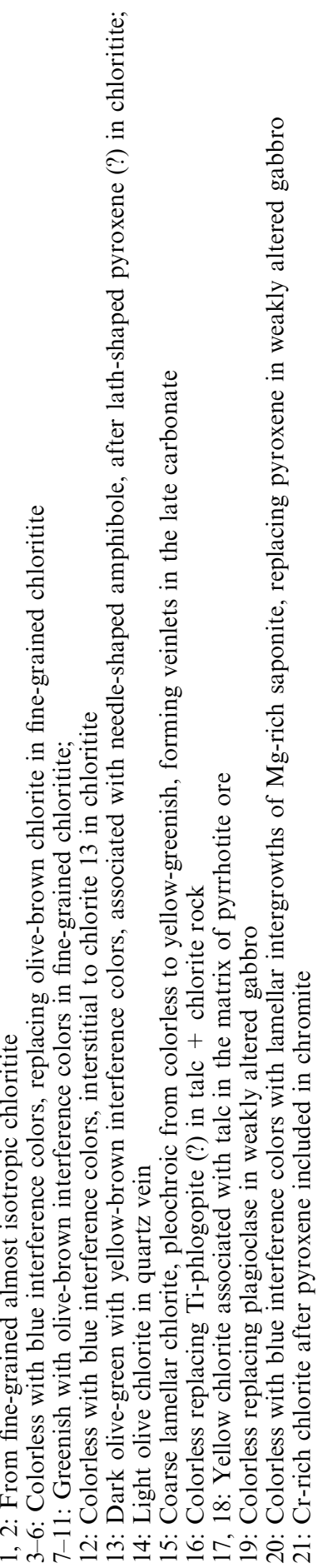


apparent octahedral vacancies

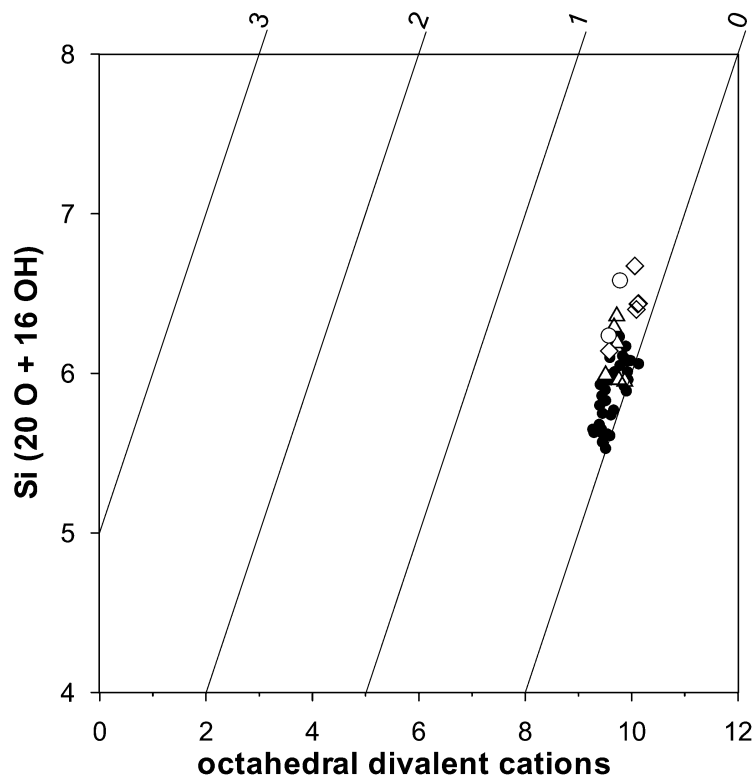

Fig. $7 \mathrm{Si}$ vs. octahedral divalent cations in the studied chlorites, showing contours for apparent octahedral vacancies based on 8 tetrahedral and 12 octahedral sites per $\mathrm{O}_{20}(\mathrm{OH})_{16}$. Filled circles Group A (chloritites after mafic protoliths); triangles Group B (associated with quartz and carbonate in veins and matrix of pyrrhotite ore); diamonds Group C (associated with talc in pyrrhotite ores); open circles Group D (weakly altered gabbro); star Group E (inclusion in chromite)

composition of this chlorite may reflect the particular chemical domain of the inclusion.

\section{Saponite}

Three groups of saponites are distinguished on the basis of their textural relations, parageneses and compositions: (a) saponites associated with the pyrrhotite ore, forming veinlets or filling voids together with other gangue minerals or replacing chlorite in sulfide-associated chloritites (Fig. 5c, d); (b) saponites in the alteration assemblages of mafic and ultramafic lithologies (Fig. 5a, b); (c) saponites replacing pyroxene + glass inclusions in chromite grains. The compositions of the analyzed saponites are reported in Table 3 and illustrated in Fig. 10. Comparison between saponite analyses obtained using standard analytical conditions $(15 \mathrm{kV}, 15 \mathrm{nA}$, and $1-\mu \mathrm{m}$ beam) and those obtained using a lower beam current (10 nA) and a defocused beam $(\varnothing=5 \mu \mathrm{m})$ indicates that analyses were affected by minor $\mathrm{Ca}, \mathrm{Na}$ and $\mathrm{K}$ loss (Table 3). The relatively high and variable oxide totals (88-94 wt\%) obtained when using standard conditions are ascribed to partial loss of interlayer water during the analysis. This effect was apparently reduced when a lower beam current and a defocused beam were used (cf. sample Iv36.0 in Table 3). Distinction from talc based on electron microprobe data alone was sometimes ambiguous due to the low proportion of interlayer cations and water loss, but generally easy under the microscope because of the markedly lower birefringence of saponite.

All analyzed saponites have very low $\mathrm{Al}, \mathrm{Ca}$, and alkalis, and usually have $\mathrm{Ca}>\mathrm{Na} \geq \mathrm{K}$ in molar proportions. The very low $\mathrm{Al}$ contents and the high $\mathrm{Mg}$ / $(\mathrm{Mg}+\mathrm{Fe})$ ratios classify them as a low- $(\mathrm{Ca}, \mathrm{Na})$ form of stevensite, the nominally $\mathrm{Al}$-free, magnesian saponite end-member with theoretical formula $\left(\mathrm{Ca}_{0.5}, \mathrm{Na}\right)_{2 \mathrm{x}} \mathrm{Mg}_{6}$ ${ }_{x} \mathrm{Si}_{8} \mathrm{O}_{20}(\mathrm{OH})_{4} \cdot \mathrm{nH}_{2} \mathrm{O}$. In ideal stevensite, the excess charge brought about by interlayer cations is balanced by vacancies in the octahedral layers. In natural samples, minor heterovalent substitutions of $\mathrm{Al}$ for Si may also contribute to the charge balance. In most of our analyses, however, there is insufficient $\mathrm{Si}+\mathrm{Al}$ to make up the
Fig. 8 Compositions of chlorites from Ivanovka drill-core DDH2T in the classification diagram of Hey (1954). Same symbols as in Fig. 7. Fields for chlorites (including chlorite-rich mixedlayer chlorite-smectites) from typical altered oceanic crust (Hole 504B, eastern Pacific) after Alt et al. (1996); fields for chlorites in oceanic hydrothermal upflow zones from Mid-Atlantic Ridge

(Kane, TAG), Galapagos, East Pacific Rise $13^{\circ} \mathrm{N}$, and IzuBonin based on compilation by Alt (1999)

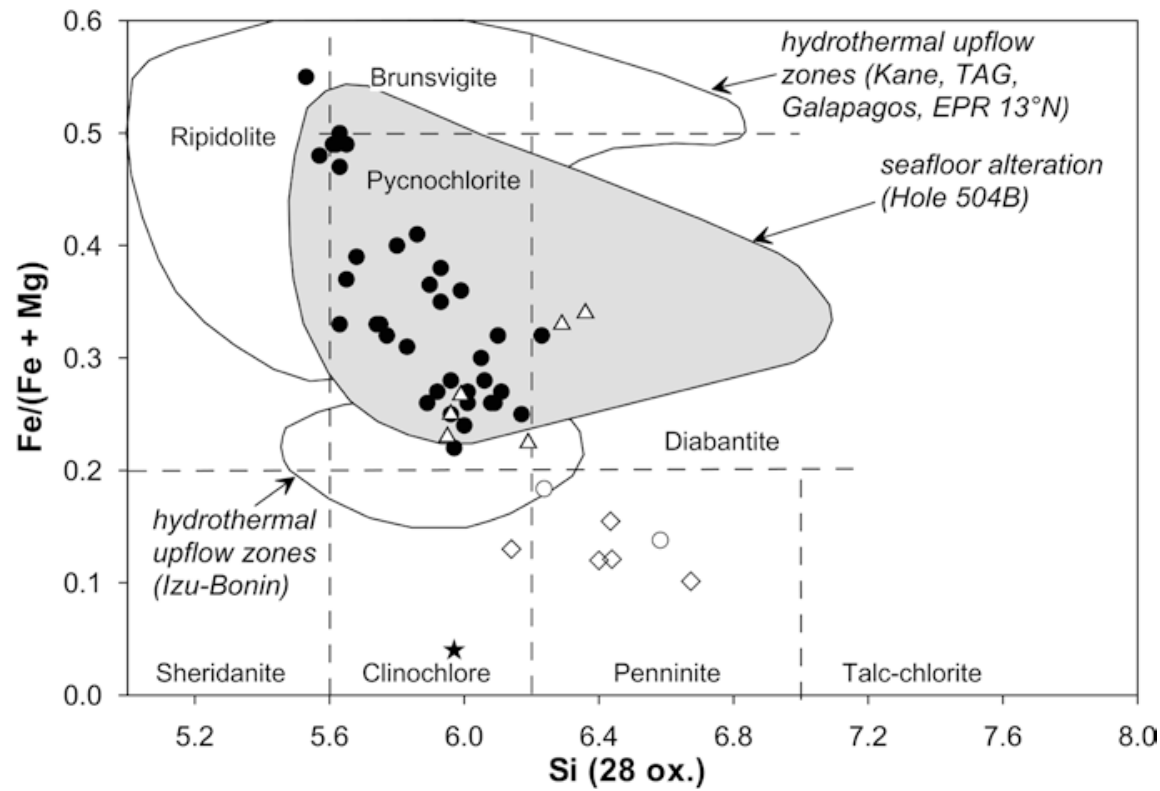


Fig. 9 Compositions of chlorites from Ivanovka drill-core DDH2T in the $\mathrm{Fe}_{\mathrm{tot}}$ $\left(\mathrm{Fe}_{\text {tot }}+\mathrm{Mg}\right)$ vs. ${ }^{[4]} \mathrm{Al}$ and $\left({ }^{[6]} \mathrm{Al}+2 \mathrm{Ti}+\mathrm{Cr}\right) / 2-1$ vs. ${ }^{[4]} \mathrm{Al} /$ 2-1 discriminatory diagrams. a, b comparison with chlorites in metabasites (fields for low-grade, greenschist and amphibolite + epidoteamphibolite facies after Laird 1988); c, d comparison with chlorites from hydrothermally altered oceanic rocks (source of data: Humphris and Thompson 1978; Alt et al. 1985, 1995, 1998; Shau and Peacor 1992; Schiffman and Staudigel 1995; Vanko et al. 1996). Same symbols as in Fig. 7
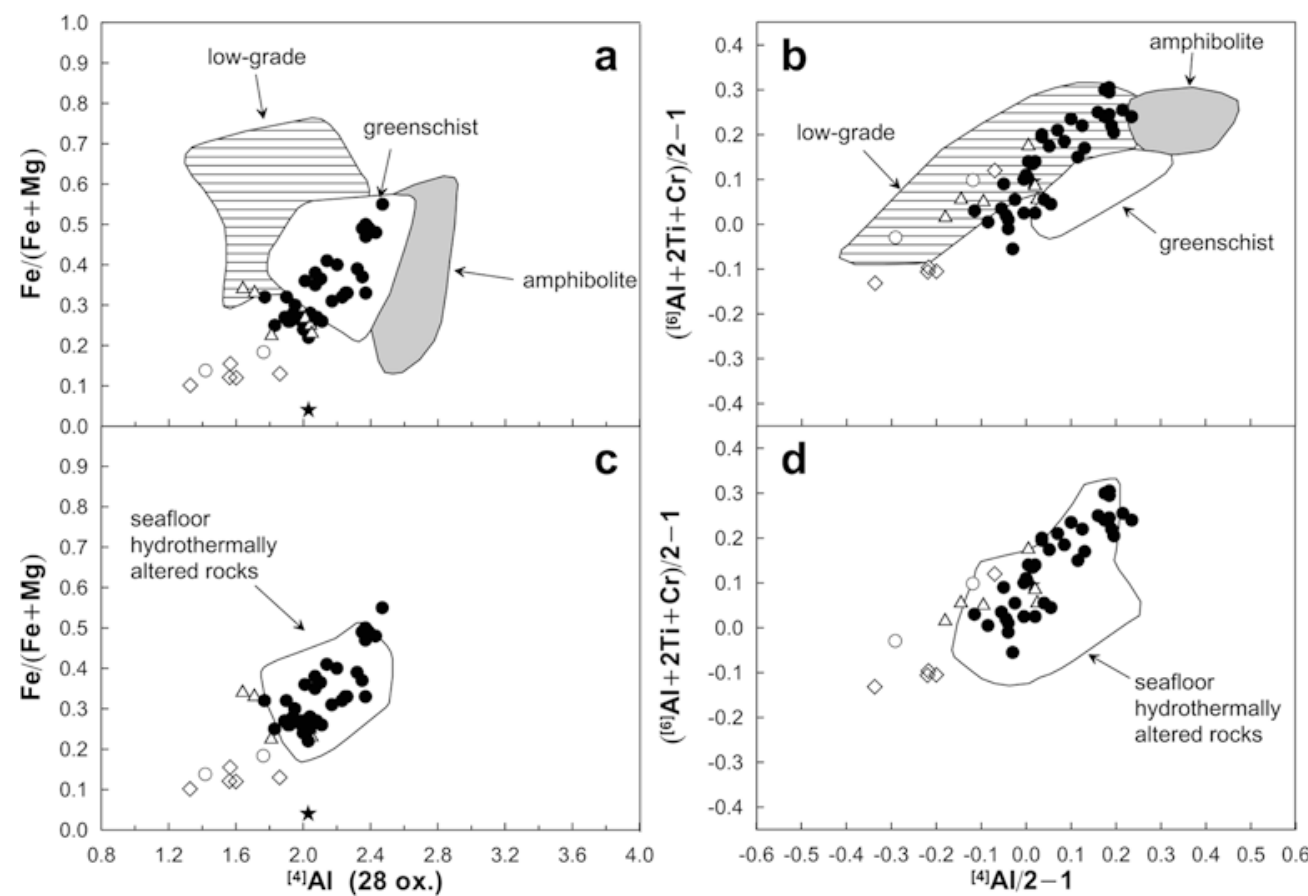

ideal eight tetrahedral atoms. This feature is relatively common in natural saponites, and often ascribed to the presence of $\mathrm{Fe}^{3+}$ in the tetrahedral layer (cf. Zierenberg and Shanks 1983; Cole 1988). For crystal-chemical formula calculations (Table 3 ) we have assumed the tetrahedral sites to be occupied by $\mathrm{Si}$ and by as much $\mathrm{Al}$ and, if necessary, $\mathrm{Fe}^{3+}$ as needed to fill up the tetrahedral layer. Remaining iron has been assigned to octahedral coordination as $\mathrm{Fe}^{2+}$.

Despite assignment of some Fe to tetrahedral coordination, the totals of nominally octahedral cations are usually slightly higher than the ideal value of 6 (range 5.99-6.24; median 6.07), possibly reflecting the presence of minor interlayer $\mathrm{Mg}$ or brucite layers or minor contamination by associated chlorite or serpentine. In order to minimize errors due to contamination, a few analyses yielding an anomalous excess of octahedral cations ( $>0.30$, being the median value 0.15$)$ were discarded. All discarded analyses could be reasonably ascribed to contamination by optically visible intergrown serpentine and chlorite rather than to mixed-layer compositions or unusually high proportions of interlayer $\mathrm{Mg}$. Saponites formed after pyroxene + glass inclusions in chromite crystals could not be analyzed at the desired quality level.

Sulfide-associated saponites (Table 3; an 1-7) have $\mathrm{Mg} /\left(\mathrm{Mg}+\mathrm{Fe}_{\text {tot. }}\right)$ ratios in the range $0.74-0.82$ (median $=0.76$ ). Saponites replacing olivine and pyroxene in melagabbroids (Table 3; an. 8-12) are distinct by their higher $\mathrm{Mg} /(\mathrm{Mg}+\mathrm{Fe}$ tot. $)$ ratios, which range between 0.82 and 0.91 (median $=0.86$ ), and show a positive $\mathrm{Mg} /\left(\mathrm{Mg}+\mathrm{Fe}_{\text {tot. }}\right)$ vs. $\mathrm{Si} /(\mathrm{Si}+\mathrm{Al})$ correlation. Saponites replacing pyroxene can be slightly enriched in $\mathrm{Al}$ and Ca.
Talc

Representative talc analyses are reported in Table 4. Based on composition and textural relations, five main types of talc can be distinguished which are characterized by increasing $\mathrm{FeO}$ contents: (a) second-stage alteration after actinolitic amphibole in gabbro $\left(\mathrm{FeO}=1.5 \mathrm{wt} \% ; \mathrm{Mg} /\left(\mathrm{Mg}+\mathrm{Fe}_{\text {tot. }}\right)=0.97\right)($ Fig. $5 \mathrm{e}) ;(\mathrm{b})$ inclusions associated with magnesian saponite in pyrrhotite laths $(\mathrm{FeO}=3.2-3.9 \mathrm{wt} \% ; \quad \mathrm{Mg} /(\mathrm{Mg}+\mathrm{Fe}$ tot. $=0.93-0.94$ ); (c) talc in talc $+\mathrm{Mg}$-saponite rock after serpentinite breccia (Iv14.0; $\mathrm{FeO}=4.7 \mathrm{wt} \% ; \mathrm{Mg} /$ $\left.\left(\mathrm{Mg}+\mathrm{Fe}{ }_{\text {tot. }}\right)=0.91\right)$; (d) talc in talc \pm chlorite rocks and second-stage alteration after chloritized pyroxene in gabbro $\left(\mathrm{FeO}=5.5-7.8 \mathrm{wt} \% ; \mathrm{Mg} /\left(\mathrm{Mg}+\mathrm{Fe}_{\text {tot. }}\right)=0.86\right.$ $0.90)$ (Fig. 5e, f, g); (e) fine matrix and veins in pyrrhotite ore $(\mathrm{FeO}=5.5-14.3 \mathrm{wt} \% ; \quad \mathrm{Mg} /(\mathrm{Mg}+\mathrm{Fe}$ tot. $)=$ $0.73-0.90)$.

Mixed-layer chlorite-smectite (?) and illite

Plagioclase crystals in partially altered gabbro sills (Iv78.5 and Iv174.7) show an initial alteration to illite (and chlorite) in patches and along fractures or cleavage planes. Representative analyses of this mineral are reported in Table 5. The low Si content, the high cation sum, and the presence of significant $\mathrm{Mg}$ and $\mathrm{Fe}$ indicate either the presence of interlayered chlorite or, more probably, contamination by associated discrete chlorite. Locally, the rims of the plagioclase crystals are subsequently replaced by a low-birefringent microcrystalline phyllosilicate having a composition consistent with that of a mixed-layer chlorite-smectite with estimated 
Table 3 Electron microprobe analyses of saponites from the Ivanovka drill-core DDH2T. Unit formulas based on 22 oxygens

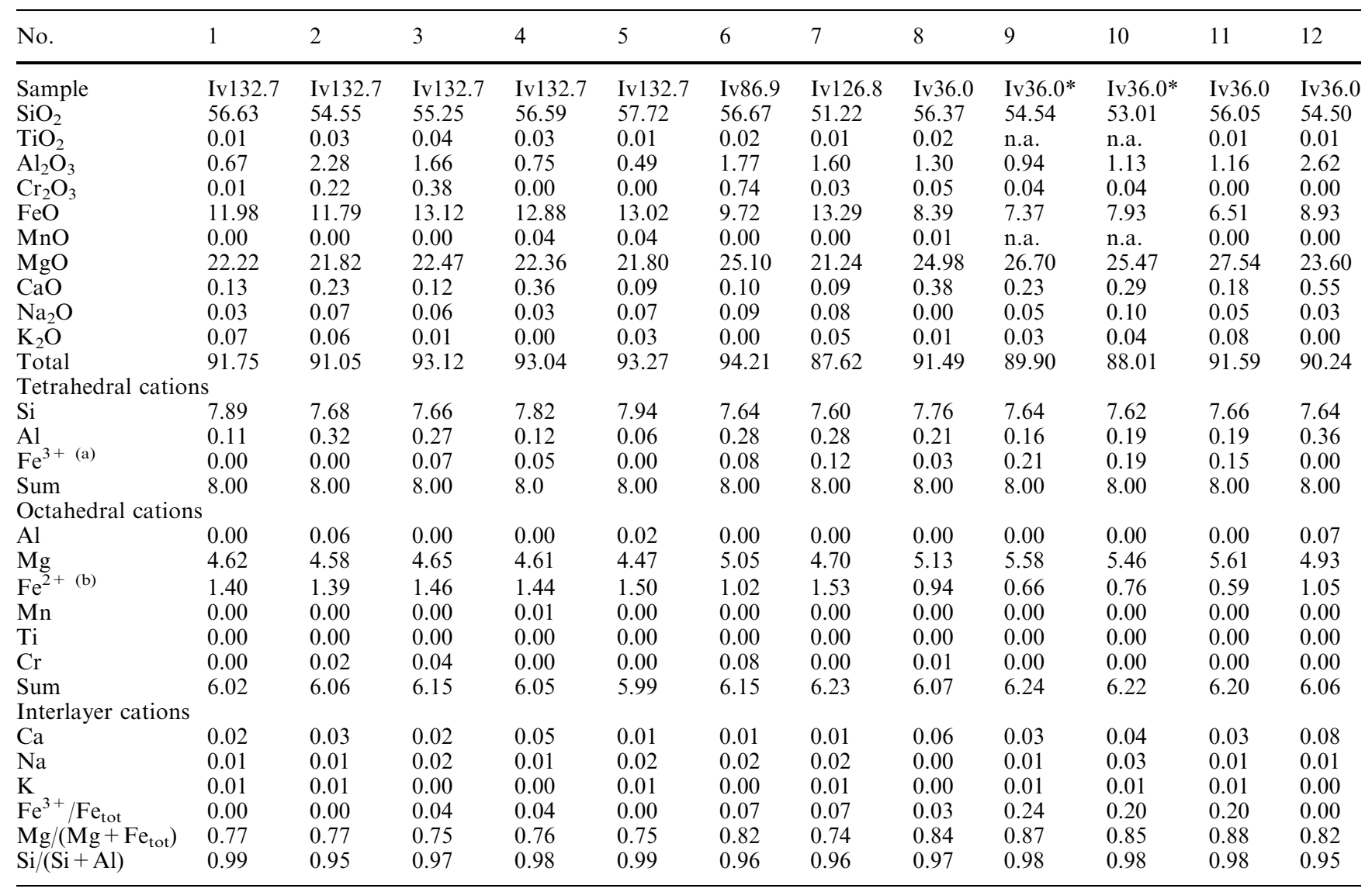

Analytical conditions: $15 \mathrm{nA}, 15 \mathrm{kV}, 1-\mu \mathrm{m}$ beam (excepting *: 5: Replacing chlorite in chloritite clast

$10 \mathrm{nA}, 15 \mathrm{kV}, 5-\mu \mathrm{m}$ defocused beam)

n.a.: Not analyzed

${ }^{\mathrm{a}}$ Calculated as $8-\mathrm{Si}-\mathrm{Al}$

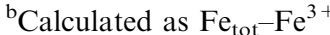

1: Veinlet crosscutting sulfide ore

2: Matrix of sulfide ore

3, 4: Associated with dolomite and chromian spinel, cementing cobaltite crystals and chloritite clasts partially altered to saponite, in vein cutting massive pyrrhotite

44-74\% of swelling components (Table 5). The small occurrences precluded X-ray identification and definition of the exact nature of this mineral.

A mineral with optical properties and chemical composition compatible with a mixed chlorite-smectite was also found in a sample from the uppermost ore level (Iv80.5). Here, chlorite-smectite (?) or, alternatively, chlorite replace the clasts of a polymict mafic breccia, which is associated with a partially dismembered mineralization made of dominant $\mathrm{Fe}$ - and $(\mathrm{Cu}, \mathrm{Fe})$-sulfides and $\mathrm{Mg}$-rich siderite. The composition of the chloritesmectite (?) in this sample is distinctively more iron-rich than in the gabbros.

\section{Serpentine}

Representative serpentine analyses are reported in Table 6 . Serpentine in massive serpentinites and in altered
6: Cementing chromian spinel fragments in pyrrhotite ore

7: Inclusion associated with talc in pyrrhotite lath 8-10: Replacing olivine phenocryst cores 11, 12: Replacing pyroxene

melagabbroids (Fig. 5a, b) has $\mathrm{Mg} /(\mathrm{Mg}+\mathrm{Fe})$ ratios in the range 0.95-0.98. The highest $\mathrm{Mg} /(\mathrm{Mg}+\mathrm{Fe})$ ratio was found in a serpentine-altered inclusion occurring in a euhedral chromite crystal. Serpentine replacing orthopyroxene in serpentinites has appreciable contents of aluminum and chromium. The relatively high measured aluminum content of serpentine in the altered melagabbroid Iv36.0 may in part reflect contamination of microprobe analysis by finely intergrown chlorite (see below).

Finely intergrown mafic phyllosilicate minerals

This group of minerals is part of the alteration assemblage formed at the expense of plagioclase and pyroxene in melagabbroic rocks (Fig. 5a, b; Table 7). Alteromorphs after poikilitic pyroxene are light brown in color and weakly pleochroic and exhibit uneven 1st to 


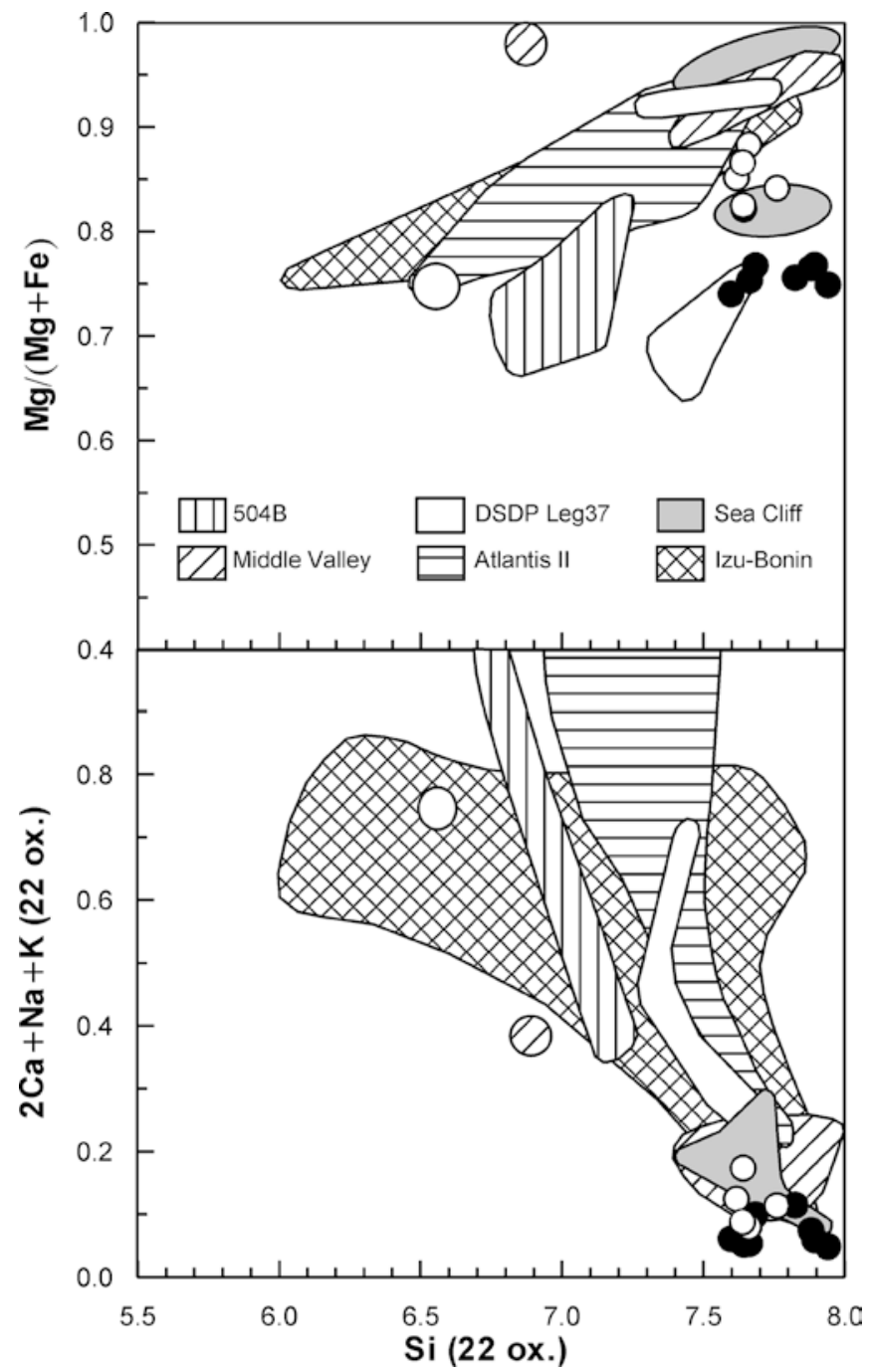

Fig. 10 Compositions of Mg-rich saponites from Ivanovka drillcore DDH2T. Filled circles ore-associated saponites; open circles saponites after olivine and pyroxenes. Fields for Mg-rich saponites from modern seafloor hydrothermal sites are shown for comparison. Source of data: 504B - Shau and Peacor (1992), Alt et al. (1995); Middle Valley - Percival and Ames (1993), Turner et al. (1993); DSDP Leg 37 - Andrews (1980); Atlantis II - Zierenberg and Shanks (1983), Cole (1988); Sea Cliff - Zierenberg et al. (1995); Izu-Bonin - Alt et al. (1998)

2nd order interference colors. Alteromorphs that probably developed after plagioclase appear as almost colorless, low-birefringent patches, often with anomalous blue interference colors, and as cryptocrystalline, lathshaped pseudomorphs with mottled gray interference colors. Under a scanning-electron microscope, these alteromorphs appear as aggregates of two finely intergrown Mg-rich silicates, characterized by slightly different brightness in back-scattered electron images and different aluminum contents.

The sequence of analyses 1 through 10 reported in Table 7 shows progressively increasing $\mathrm{SiO}_{2}$ (36$46 \mathrm{wt} \%)$ and decreasing $\mathrm{Al}_{2} \mathrm{O}_{3}(10-2 \mathrm{wt} \%)$. $\mathrm{MgO}$ contents are high $(32-37 \mathrm{wt} \%)$ and negatively correlated with $\mathrm{FeO}(10-4 \mathrm{wt} \%)$. Minor amounts of $\mathrm{CaO}(0.2-$
$0.8 \mathrm{wt} \%$ ) are present, whereas $\mathrm{Ti}, \mathrm{Cr}$ (with the exception of analyses 7 and 9 with ca. 1 wt $\% \mathrm{Cr}_{2} \mathrm{O}_{3}$ ), $\mathrm{Mn}, \mathrm{Na}, \mathrm{K}$ are very low or below detection limits. When recalculated on a 28-oxygen basis (chlorite basis), these compositions yield apparent proportions of chlorite vs. swelling components lower than $90 \%$ and plot in the talc-chlorite field of Hey (1954). The composition showing the lowest $\mathrm{Si}$ and highest $\mathrm{Al}$ contents (Table 7, analysis 1) approaches that of the high-silica Mg-rich chlorites (Table 2, analysis 16). Analysis 8 in Table 7 compares well with some Al-rich serpentine analyses from the literature (e.g. Lapham 1958; Christofides et al. 1994; Melcher et al. 1997) and, although at somewhat higher Al levels, with serpentine analysis 4 reported in Table 6 . The analyses showing the highest $\mathrm{Si} /(\mathrm{Si}+\mathrm{Al})$ ratios and $\mathrm{SiO}_{2}$ contents (analyses 9 and 10) pertain to alteromorphs after poikilitic pyroxene and approach the compositions of Mg-rich saponite (cf. Table 3).

All these observations suggest that the mineral compositions reported in Table 7 do not represent discrete, chemically variable mineral phases, nor mixed-layer chlorite-smectite, talc-chlorite or serpentine-chlorite. Measured compositions are interpreted to reflect finegrained mixtures of $\mathrm{Mg}$-rich chlorite with serpentine and/or Mg-rich saponite. The latter appears to be predominant in alteromorphs after pyroxene, in line with the occurrence of optically observable saponite in the alteromorphs. An indirect confirmation of the nature of the minerals is provided by whole-rock XRD analysis of two samples (Iv32.0 and Iv33.6), petrographically similar and spatially close to samples Iv36.0 and Iv44.0, which revealed the presence of the dominant mineral phases serpentine, talc, Mg-rich chlorite \pm saponite, plus minor magnetite and chromite.

\section{Comparison with chlorite, saponite and talc in ancient and modern hydrothermal settings}

\section{Chlorite}

The positive correlation between $\mathrm{Fe} /(\mathrm{Fe}+\mathrm{Mg})$ ratio and ${ }^{[4]} \mathrm{Al}$ content shown by the studied chlorites (Fig. 9a, c) is common in chlorites of both metamorphic and hydrothermal origin (e.g. Hey 1954; Costa et al. 1983; McLeod and Stanton 1984; Zhong et al. 1985; Kranidiotis and MacLean 1987; Bettison and Schiffman 1988; Zang and Fyfe 1995). Covariation of $\mathrm{Al}$ and $\mathrm{Fe} /$ $(\mathrm{Fe}+\mathrm{Mg})$ is favored by cation size change and structural adjustments in the chlorite crystal lattice and may reflect variations in protolith bulk chemistry, variable degree of hydrothermal alteration, changes in hydrothermal fluid composition and temperature (e.g. Saccoccia and Seyfried 1994). The effect of local compositional factors is observable in our chloritites after mafic rocks characterized by intersertal texture. In these rocks, the original mineral compositions and crystal chemical constraints clearly led to replacement of the euhedral intersertal mineral, probably a plagioclase, by high-(Al, $\mathrm{Fe})$ 
Table 4 Electron microprobe analyses of talc from the Ivanovka drill-core DDH2T. Unit formulas based on 22 oxygens
1, 2: Inclusions, associated with Mg-rich saponite, in a pyrrhotite lath

3: Associated with dolomite in vein cutting massive pyrrhotite 4-6: Fine matrix in pyrrhotite ore

7: Coarse, forming a clast of a talc rock set in a fine talc matrix (cf. analysis 5)

8: Second-stage alteration after actinolite in gabbro

9, 10: Main constituent of talc \pm chlorite rock

11: Main constituent of talc rock

\begin{tabular}{|c|c|c|c|c|c|c|c|c|c|c|c|}
\hline No. & 1 & 2 & 3 & 4 & 5 & 6 & 7 & 8 & 9 & 10 & 11 \\
\hline Sample & \multicolumn{11}{|c|}{ Iv126.8 Iv126.8 Iv132. } \\
\hline $\mathrm{SiO}_{2}$ & 62.98 & 62.93 & 58.95 & 59.26 & 61.42 & 59.88 & 61.11 & 64.09 & 62.57 & 63.13 & 62.30 \\
\hline $\mathrm{TiO}_{2}$ & 0.01 & 0.00 & 0.00 & 0.01 & 0.01 & 0.02 & 0.00 & 0.06 & 0.01 & 0.01 & 0.01 \\
\hline $\mathrm{Al}_{2} \mathrm{O}_{3}$ & 0.00 & 0.02 & 0.53 & 0.00 & 0.16 & 0.48 & 0.26 & 0.46 & 0.14 & 0.15 & 0.08 \\
\hline $\mathrm{Cr}_{2} \mathrm{O}_{3}$ & 0.01 & 0.01 & 0.00 & 0.04 & 0.00 & 0.12 & 0.13 & 0.07 & 0.05 & 0.00 & 0.11 \\
\hline $\mathrm{FeO}$ & 3.22 & 3.94 & 13.52 & 14.34 & 5.49 & 10.48 & 9.14 & 1.45 & 5.52 & 7.22 & 7.76 \\
\hline $\mathrm{MnO}$ & 0.08 & 0.01 & 0.03 & 0.00 & 0.02 & 0.00 & 0.04 & 0.01 & 0.00 & 0.04 & 0.03 \\
\hline $\mathrm{MgO}$ & 29.51 & 29.42 & 22.07 & 21.70 & 27.31 & 23.81 & 25.15 & 31.70 & 28.17 & 26.85 & 26.99 \\
\hline $\mathrm{CaO}$ & 0.00 & 0.00 & 0.05 & 0.02 & 0.02 & 0.05 & 0.03 & 0.01 & 0.05 & 0.04 & 0.03 \\
\hline $\mathrm{Na}_{2} \mathrm{O}$ & 0.01 & 0.00 & 0.05 & 0.00 & 0.02 & 0.04 & 0.10 & 0.10 & 0.03 & 0.01 & 0.01 \\
\hline $\mathrm{K}_{2} \mathrm{O}$ & 0.00 & 0.00 & 0.00 & 0.01 & 0.01 & 0.01 & 0.02 & 0.01 & 0.02 & 0.00 & 0.00 \\
\hline Total & 95.82 & 96.33 & 95.20 & 95.38 & 94.46 & 94.90 & 95.96 & 97.95 & 96.56 & 97.44 & 97.32 \\
\hline $\mathrm{Si}$ & 8.02 & 8.00 & 7.95 & 8.00 & 8.02 & 7.98 & 8.00 & 7.93 & 8.00 & 8.04 & 7.98 \\
\hline $\mathrm{Al}$ & 0.00 & 0.00 & 0.08 & 0.00 & 0.02 & 0.08 & 0.04 & 0.07 & 0.02 & 0.02 & 0.01 \\
\hline $\mathrm{Mg}$ & 5.60 & 5.58 & 4.44 & 4.37 & 5.32 & 4.73 & 4.91 & 5.85 & 5.37 & 5.10 & 5.16 \\
\hline $\mathrm{Fe}$ & 0.34 & 0.42 & 1.52 & 1.62 & 0.60 & 1.17 & 1.00 & 0.15 & 0.59 & 0.77 & 0.83 \\
\hline $\mathrm{Mn}$ & 0.01 & 0.00 & 0.00 & 0.00 & 0.00 & 0.00 & 0.00 & 0.00 & 0.00 & 0.00 & 0.00 \\
\hline $\mathrm{Ti}$ & 0.00 & 0.00 & 0.00 & 0.00 & 0.00 & 0.00 & 0.00 & 0.01 & 0.00 & 0.00 & 0.00 \\
\hline $\mathrm{Cr}$ & 0.00 & 0.00 & 0.00 & 0.00 & 0.00 & 0.00 & 0.00 & 0.01 & 0.00 & 0.00 & 0.01 \\
\hline $\mathrm{Ca}$ & 0.00 & 0.00 & 0.01 & 0.00 & 0.00 & 0.01 & 0.00 & 0.00 & 0.01 & 0.00 & 0.00 \\
\hline K & 0.00 & 0.00 & 0.01 & 0.00 & 0.00 & 0.00 & 0.00 & 0.02 & 0.01 & 0.00 & 0.00 \\
\hline $\mathrm{Na}$ & 0.00 & 0.00 & 0.00 & 0.00 & 0.01 & 0.01 & 0.02 & 0.00 & 0.00 & 0.00 & 0.00 \\
\hline Sum & 13.97 & 14.00 & 14.02 & 14.00 & 13.97 & 13.98 & 13.97 & 14.04 & 14.00 & 13.95 & 14.01 \\
\hline $\mathrm{Mg} /(\mathrm{Mg}+$ & Fe) 0.94 & 0.93 & 0.74 & 0.73 & 0.90 & 0.80 & 0.83 & 0.97 & 0.90 & 0.87 & 0.86 \\
\hline
\end{tabular}

Table 5 Electron microprobe analyses of chlorite-smectite (?) and illite from Ivanovka drill-core DDH2T. Unit formulas based on 28 oxygens for chlorite-smectite and 22 oxygens for illite

\begin{tabular}{|c|c|c|c|c|c|c|}
\hline No. & 1 & 2 & 3 & 4 & 5 & 6 \\
\hline Sample & Iv80.5 & Iv80.5 & Iv174.7 & Iv174.7 & Iv78.5 & Iv174.7 \\
\hline $\mathrm{SiO}_{2}$ & 31.93 & 34.07 & 35.00 & 36.92 & 45.44 & 47.05 \\
\hline $\mathrm{TiO}_{2}$ & 0.06 & 0.00 & 0.02 & 0.04 & n.a. & 0.03 \\
\hline $\mathrm{Al}_{2} \mathrm{O}_{3}$ & 17.67 & 16.33 & 15.64 & 19.43 & 32.28 & 33.57 \\
\hline $\mathrm{Cr}_{2} \mathrm{O}_{3}$ & 0.07 & 0.14 & 0.00 & 0.00 & 0.07 & 0.00 \\
\hline $\mathrm{FeO}$ & 19.02 & 21.61 & 8.24 & 6.87 & 1.69 & 1.41 \\
\hline $\mathrm{MnO}$ & 0.08 & 0.00 & 0.06 & 0.09 & n.a. & 0.02 \\
\hline $\mathrm{MgO}$ & 17.99 & 22.43 & 26.25 & 22.29 & 3.60 & 3.54 \\
\hline $\mathrm{CaO}$ & 0.03 & 0.08 & 0.15 & 0.12 & 0.42 & 0.62 \\
\hline $\mathrm{Na}_{2} \mathrm{O}$ & 0.14 & 0.51 & 0.84 & 0.54 & 0.11 & 0.25 \\
\hline $\mathrm{K}_{2} \mathrm{O}$ & 0.01 & 0.09 & 0.18 & 0.33 & 7.76 & 7.86 \\
\hline Total & 87.02 & 85.26 & 86.39 & 86.63 & 91.37 & 94.35 \\
\hline $\mathrm{Si}$ & 6.47 & 7.10 & 6.77 & 6.98 & 6.24 & 6.24 \\
\hline $\mathrm{Al}$ & 4.22 & 4.01 & 3.56 & 4.33 & 5.22 & 5.25 \\
\hline $\mathrm{Ti}$ & 0.01 & 0.00 & 0.00 & 0.01 & - & 0.00 \\
\hline $\mathrm{Cr}$ & 0.01 & 0.02 & 0.00 & 0.00 & 0.01 & 0.00 \\
\hline $\mathrm{Fe}$ & 3.22 & 3.76 & 1.33 & 1.09 & 0.19 & 0.16 \\
\hline $\mathrm{Mn}$ & 0.01 & 0.00 & 0.01 & 0.01 & - & 0.00 \\
\hline $\mathrm{Mg}$ & 5.43 & 3.86 & 7.56 & 6.28 & 0.74 & 0.70 \\
\hline $\mathrm{Ca}$ & 0.01 & 0.02 & 0.03 & 0.02 & 0.06 & 0.09 \\
\hline $\mathrm{Na}$ & 0.06 & 0.21 & 0.31 & 0.20 & 0.03 & 0.06 \\
\hline $\mathrm{K}$ & 0.00 & 0.02 & 0.04 & 0.08 & 1.36 & 1.33 \\
\hline Sum & 19.44 & 19.00 & 19.61 & 19.00 & 13.84 & 13.83 \\
\hline $\mathrm{Mg} /(\mathrm{Mg}+\mathrm{Fe})$ & 0.63 & 0.51 & 0.85 & 0.85 & 0.79 & 0.82 \\
\hline$\%$ Chl & 69 & 45 & 74 & 44 & & \\
\hline
\end{tabular}

n.a.: not analyzed

1: Chlorite-smectite (?) - replacing clasts of mafic rocks associated with lamellar pyrrhotite + carbonate + chlorite mineralization

2: smectite-chlorite (?) - veinlet cutting the above

3, 4: Chlorite-smectite (?) and smectite-chlorite (?) - second-stage alteration after plagioclase in gabbro

5 , 6: Illite - replacing plagioclase in gabbro "olive-brown" chlorites and of the interstitial matrix by low-(Al, Fe) "blue" chlorites, respectively. Variations in hydrothermal physico-chemical conditions, as well as local chemical rehomogenization, may account for par-

Table 6 Electron microprobe analyses of serpentine from the Ivanovka deposit. Unit formulas based on $9(\mathrm{O}, \mathrm{OH})$

\begin{tabular}{|c|c|c|c|c|}
\hline No. & 1 & 2 & 3 & 4 \\
\hline Sample & Iv10* & Iv $10 *$ & $\operatorname{Iv} 10^{a}$ & Iv36.0 \\
\hline Original lithology & \multicolumn{3}{|c|}{ Harzburgite } & Mela-gabbroid \\
\hline $\mathrm{SiO}_{2}$ & 44.26 & 42.85 & 44.80 & 44.13 \\
\hline $\mathrm{TiO}_{2}$ & 0.00 & 0.06 & 0.02 & 0.06 \\
\hline $\mathrm{Al}_{2} \mathrm{O}_{3}$ & 0.16 & 0.71 & 0.25 & 0.77 \\
\hline $\mathrm{Cr}_{2} \mathrm{O}_{3}$ & 0.06 & 0.61 & 1.17 & 0.00 \\
\hline $\mathrm{FeO}$ & 2.40 & 3.61 & 1.83 & 3.80 \\
\hline $\mathrm{MnO}$ & 0.04 & 0.08 & 0.00 & 0.05 \\
\hline $\mathrm{MgO}$ & 40.17 & 37.69 & 40.26 & 39.86 \\
\hline $\mathrm{CaO}$ & 0.03 & 0.10 & 0.06 & 0.04 \\
\hline $\mathrm{Na}_{2} \mathrm{O}$ & 0.00 & 0.00 & 0.00 & 0.00 \\
\hline $\mathrm{K}_{2} \mathrm{O}$ & 0.00 & 0.00 & 0.00 & 0.00 \\
\hline Total & 87.12 & 85.72 & 88.40 & 88.71 \\
\hline $\mathrm{Si}$ & 2.05 & 2.04 & 2.05 & 2.03 \\
\hline $\mathrm{Al}$ & 0.01 & 0.04 & 0.01 & 0.04 \\
\hline $\mathrm{Mg}$ & 2.78 & 2.68 & 2.74 & 2.73 \\
\hline $\mathrm{Fe}$ & 0.09 & 0.15 & 0.07 & 0.15 \\
\hline $\mathrm{Mn}$ & 0.00 & 0.00 & 0.00 & 0.00 \\
\hline $\mathrm{Ti}$ & 0.00 & 0.00 & 0.00 & 0.00 \\
\hline $\mathrm{Cr}$ & 0.00 & 0.02 & 0.04 & 0.00 \\
\hline $\mathrm{Ca}$ & 0.00 & 0.01 & 0.00 & 0.00 \\
\hline $\mathrm{K}$ & 0.00 & 0.00 & 0.00 & 0.00 \\
\hline $\mathrm{Na}$ & 0.00 & 0.00 & 0.00 & 0.00 \\
\hline Sum & 4.93 & 4.93 & 4.91 & 4.95 \\
\hline $\mathrm{Mg} /(\mathrm{Mg}+\mathrm{Fe})$ & 0.97 & 0.95 & 0.98 & 0.95 \\
\hline
\end{tabular}

1: Replacing olivine

2: Replacing orthopyroxene

3: Replacing inclusion in euhedral chromite crystal

4: Replacing a lath-shaped crystal (plagioclase?)

${ }^{\text {a }}$ Sample taken from outcrop 
Table 7 Electron microprobe analyses of finely intergrown mafic phyllosilicates in altered melagabbroids from Ivanovka drill-core DDH2T. Unit formulas based on 22 oxygens

1-3, 5, 8: Matrix between altered olivine and pyroxene crystals, probably replacing interstitial plagioclase; colorless with blue interference colors 4, 7: Associated with Mg-rich saponite, replacing pyroxene 6: Rim with fibrous appearance between an altered olivine crystal and interstitial matrix (ex-plagioclase?)

9-10: Replacing pyroxene

\begin{tabular}{lllllllllll}
\hline $\mathrm{No}$. & 1 & 2 & 3 & 4 & 5 & 6 & 7 & 8 & 9 & 10 \\
\hline $\mathrm{Sample}$ & Iv44.0 & Iv36.0 & Iv36.0 & Iv36.0 & Iv36.0 & Iv36.0 & Iv44.0 & Iv36.0 & Iv44.0 & Iv44.0 \\
$\mathrm{SiO}_{2}$ & 36.39 & 38.82 & 38.34 & 39.49 & 40.11 & 40.35 & 39.30 & 40.14 & 43.24 & 46.32 \\
$\mathrm{TiO}_{2}$ & 0.00 & 0.00 & 0.00 & 0.03 & 0.01 & 0.02 & 0.12 & 0.00 & 0.07 & 0.09 \\
$\mathrm{Al}_{2} \mathrm{O}_{3}$ & 9.49 & 9.23 & 7.98 & 7.13 & 6.46 & 4.52 & 4.21 & 4.32 & 3.73 & 1.88 \\
$\mathrm{Cr}_{2} \mathrm{O}_{3}$ & 0.09 & 0.02 & 0.02 & 0.00 & 0.11 & 0.06 & 1.24 & 0.01 & 1.07 & 0.22 \\
$\mathrm{FeO}$ & 7.02 & 3.97 & 4.54 & 5.88 & 5.62 & 7.16 & 7.19 & 4.16 & 7.15 & 9.61 \\
$\mathrm{MnO}$ & 0.08 & 0.00 & 0.00 & 0.00 & 0.08 & 0.04 & 0.00 & 0.00 & 0.00 & 0.00 \\
$\mathrm{MgO}$ & 32.56 & 34.18 & 34.72 & 33.84 & 34.77 & 33.27 & 33.12 & 37.16 & 32.86 & 31.56 \\
$\mathrm{CaO}$ & 0.27 & 0.77 & 0.25 & 0.15 & 0.20 & 0.25 & 0.20 & 0.30 & 0.18 & 0.23 \\
$\mathrm{Na}{ }_{2} \mathrm{O}$ & 0.00 & 0.02 & 0.00 & 0.00 & 0.03 & 0.02 & 0.03 & 0.00 & 0.00 & 0.02 \\
$\mathrm{~K} 2 \mathrm{O}$ & 0.03 & 0.00 & 0.00 & 0.01 & 0.00 & 0.01 & 0.02 & 0.00 & 0.00 & 0.00 \\
$\mathrm{Total}$ & 85.93 & 87.05 & 85.87 & 86.53 & 87.40 & 85.71 & 85.43 & 86.08 & 88.29 & 89.93 \\
$\mathrm{Si}$ & 5.54 & 5.72 & 5.75 & 5.90 & 5.94 & 6.13 & 6.03 & 6.00 & 6.36 & 6.72 \\
$\mathrm{Al}$ & 1.70 & 1.60 & 1.41 & 1.26 & 1.13 & 0.81 & 0.76 & 0.76 & 0.65 & 0.32 \\
$\mathrm{Mg}$ & 7.39 & 7.52 & 7.76 & 7.54 & 7.67 & 7.54 & 7.58 & 8.28 & 7.20 & 6.82 \\
$\mathrm{Fe}$ & 0.89 & 0.49 & 0.57 & 0.74 & 0.70 & 0.92 & 0.92 & 0.52 & 0.88 & 1.17 \\
$\mathrm{Mn}$ & 0.01 & 0.00 & 0.00 & 0.00 & 0.01 & 0.01 & 0.00 & 0.00 & 0.00 & 0.00 \\
$\mathrm{Ti}$ & 0.00 & 0.00 & 0.00 & 0.00 & 0.00 & 0.00 & 0.01 & 0.00 & 0.01 & 0.01 \\
$\mathrm{Cr}$ & 0.01 & 0.00 & 0.00 & 0.00 & 0.01 & 0.01 & 0.15 & 0.00 & 0.12 & 0.02 \\
$\mathrm{Ca}$ & 0.04 & 0.12 & 0.04 & 0.02 & 0.03 & 0.04 & 0.03 & 0.05 & 0.03 & 0.04 \\
$\mathrm{~K}$ & 0.01 & 0.00 & 0.00 & 0.00 & 0.00 & 0.00 & 0.00 & 0.00 & 0.00 & 0.01 \\
$\mathrm{Na}$ & 0.00 & 0.01 & 0.00 & 0.00 & 0.01 & 0.01 & 0.01 & 0.00 & 0.00 & 0.00 \\
$\mathrm{Sum}$ & 15.60 & 15.47 & 15.54 & 15.46 & 15.49 & 15.46 & 15.50 & 15.61 & 15.25 & 15.10 \\
$\mathrm{Mg} /(\mathrm{Mg}+\mathrm{Fe})$ & 0.89 & 0.94 & 0.93 & 0.91 & 0.92 & 0.89 & 0.89 & 0.94 & 0.89 & 0.85 \\
$\mathrm{Si} /(\mathrm{Si}+\mathrm{Al})$ & 0.76 & 0.78 & 0.80 & 0.82 & 0.84 & 0.88 & 0.89 & 0.89 & 0.91 & 0.95 \\
$\mathrm{Ni}$ & & & & & & & & & &
\end{tabular}

Table 8 Oxygen isotopic and modal compositions of representative altered rocks from the Ivanovka deposit

\begin{tabular}{|c|c|c|c|c|}
\hline Sample & Protolith & Modal composition & ${ }^{18} \mathrm{O}(\% \mathrm{~V}-\mathrm{SMOW})$ & $T\left({ }^{\circ} \mathrm{C}\right)^{\mathrm{a}}$ \\
\hline Iv33.6 & Melagabbroid & $66 \%$ Serp $+20 \% \mathrm{Chl}+8 \%$ Sap $+6 \%$ Mt (tr. Chr) & +0.1 & $187-244$ \\
\hline Iv93.0 & Ultramafic $^{\mathrm{b}}$ & $65 \% \mathrm{Tc}+33 \%$ Carb $+1 \%$ Sul $+1 \%$ Qtz (tr. Chl) & +7.8 & $123-158$ \\
\hline Iv136.0 & Mafic & $70 \% \mathrm{Chl}+30 \%$ Sap (tr. rutile) & +1.3 & $192-235$ \\
\hline Iv166.2 & Mafic & Chl (tr. rutile) & -1.3 & $239-340$ \\
\hline Iv176.2 & Ultramafic $^{\mathrm{b}}$ & $53 \% \mathrm{Tc}+37 \% \mathrm{Sul}+9 \% \mathrm{Carb}+1 \% \mathrm{Chr}(\operatorname{tr} . \mathrm{Chl})$ & +8.3 (Tc separate) & $121-146$ \\
\hline Iv209 & Mafic $^{\mathrm{c}}$ & Chl (tr. rutile) & -0.5 & $218-283$ \\
\hline
\end{tabular}

${ }^{a}$ Minimum and maximum estimates calculated assuming fluid $\delta^{18} \mathrm{O}$ of $-3 \%$ and $-1 \%$, respectively (see text)

${ }^{\mathrm{b}}$ Brecciated talc-rich rocks cemented by carbonate-sulfide veins

${ }^{\mathrm{c}}$ Altered pillow lava from outcrop

Abbreviations and source of oxygen fractionation coefficients: Carb carbonate (Kim and O'Neil 1997); Chl Mg-chlorite (Cole and

tial substitution of some early-stage "olive-brown" chlorites by later "blue" chlorites in some chloritites.

Although the association with sulfides leaves little doubt as to the hydrothermal nature of most of the studied chlorites, a metamorphic origin cannot be excluded in all cases using textural arguments alone. In particular, some chlorites occurring in alteromorphs after plagioclase, pyroxene and mica could in principle have formed during an early stage of greenschist regional metamorphism. A detailed inspection of compositional relations in our chlorites may shed further light on their origin. Several classificatory plots have been proposed to discriminate chlorites from various environments (e.g. Shikazono and Kawahata 1987; Laird 1988). In the ${ }^{[4]} \mathrm{Al}$ vs. $\mathrm{Fe} /(\mathrm{Fe}+\mathrm{Mg})$ and $\left({ }^{[4]} \mathrm{Al} / 2-1\right)$ vs. $\left[\left({ }^{[6]} \mathrm{Al}+2 \mathrm{Ti}+\mathrm{Cr}\right) / 2-1\right]$ diagrams (Fig. 9c, d), most of the studied chlorites fall in the fields of seafloor hydrothermally-altered rocks. When compared with metamorphic
Ripley 1998); Chr relict Mg-chromite; Mt magnetite (Zheng and Simon 1991); Qtz quartz (Zheng 1993a); Sap Mg-saponite (Escande et al. 1984); Serp serpentine (Zheng 1993b); Sul sulfides; Tc talc (Zheng 1993b); tr. traces $(<1 \%)$

chlorites in mafic rocks the studied chlorites plot in either the greenschist- or the zeolite-facies field, depending on the diagram used (Fig. 9a, b). The above observations suggest that all the studied chlorites developed by hydrothermal processes rather than regional metamorphism.

Group-C, Group-D and Group-E chlorites are unusually Mg-rich compared to typical seafloor hydrothermal chlorite. For Group-C (chlorites associated with talc in both sulfide-rich and barren samples), the ironpoor composition may reflect the bulk chemistry of the protolith (ultramafic), but may as well indicate a higher temperature or a lower $\mathrm{Fe} / \mathrm{Mg}$ ratio of the hydrothermal fluid (Saccoccia and Seyfried 1994). A low Fe/Mg ratio was probably responsible for the low-Fe composition of chlorites in weakly altered gabbros (Group D), for which a high- $T$ can reasonably be excluded based on the presence of saponite in the alteration assemblage 
(see below). Iron-poor fluids could derive from either a high contribution of unmodified seawater or abundant precipitation of pyrrhotite in the rock or in nearby mineralized levels.

As for the Cr-rich clinochlore included in a chromite grain from sample Iv175.8 (Group E), we note that similar chlorites, in association with serpentine, are widespread as inclusions, clots, fracture fillings and veins in chromites from ophiolite massifs (Christofides et al. 1994; Melcher et al. 1997). The particularly iron-poor composition can be ascribed in part to chemical exchange at low temperature with the chromite host.

We have not attempted to apply the rather popular "chlorite geothermometer" (Cathelineau and Nieva 1985; Cathelineau 1988; Zang and Fyfe 1995; Xie et al. 1997) to our chlorites, because the general validity of the empirical ${ }^{[4]} \mathrm{Al}$ vs. $T$ approach used by this method is questionable (Shau et al. 1990; de Caritat et al. 1993; Jiang et al. 1994). In particular, Jiang et al. (1994) have shown that the decrease in ${ }^{[4]} \mathrm{Al}$ with decreasing temperature in the data used for the geothermometer calibration is associated with a significant increase in both apparent octahedral vacancies and $(\mathrm{Na}+\mathrm{K}+2 \mathrm{Ca})$ content, which is best explained if the electron microprobe analyses were compromised by contamination of the chlorite due to the small crystal size or to the presence of mixed layers. Whatever the nature of the vacancies, this trend is not shown by our chlorites, which maintain uniformly low apparent octahedral vacancies regardless their ${ }^{[4]} \mathrm{Al}$ content (Fig. 7). Any thermometric extrapolation of the Cathelineau and Nieva (1985) ${ }^{\left[{ }^{[4}\right.} \mathrm{Al}$ vs. $T$ empirical correlation and of its later modifications to our chlorite compositions is therefore unwarranted.

\section{Saponite}

Magnesium-silicon-rich saponite, often in the form of nearly end-member stevensite, is a relatively common mineral in some hydrothermal fields from modern oceanic environments and a typical alteration product of basalt in experimental basalt-seawater systems. To our knowledge, however, stevensite has never been reported in ancient hydrothermal massive sulfide deposits found on-land, where more aluminous or ferrous smectites or mixed-layer chlorite-smectites are instead relatively common (e.g. Richards et al. 1989). The apparent rarity of stevensite in ancient deposits may reflect either differences in hydrothermal physicochemical conditions between ancient and modern settings or, more probably, modification of the original phyllosilicate compositions during later hydrothermal circulation or metamorphism.

Typical modern occurrences of stevensite include alteration products after mafic-intermediate volcanic rocks and basaltic hyaloclastites (Andrews 1980; Shau and Peacor 1992; Zierenberg et al. 1995; Alt et al. 1998; Alt and Teagle 2003), replacement of higher- $T$ hydrothermal talc (Shau and Peacor 1992), hydrothermal seafloor precipitates, chimneys and mounds (Peter and Scott 1988; Percival and Ames 1993; Turner et al. 1993), and epigenetic hydrothermal veins within unconsolidated sediments (Zierenberg and Shanks 1988; Cole 1988). A typical mineral association in the hydrothermal precipitates is that of stevensite with platy pyrrhotite, an assemblage interpreted to derive from mixing of hot hydrothermal fluid and ambient seawater (Peter and Scott 1988). This association is strictly comparable with that found in the uppermost level of the Ivanovka main massive sulfide orebody ( $80.5 \mathrm{~m}$ depth; Figs. 3 and 4). Relations between $\mathrm{Si}, \mathrm{Mg} /(\mathrm{Mg}+\mathrm{Fe})$ and interlayer charge show that our saponites compare well with the most Si-rich saponites from hydrothermal deposits and hydrothermally altered rocks of modern ocean seafloors (Fig. 10).

The composition of hydrothermal saponite is controlled by a number of factors and processes, including temperature, composition of the hydrothermal fluid, partitioning of iron into associated sulfides or oxides and local element release during alteration. Available estimates of the temperatures of formation of $(\mathrm{Mg}, \mathrm{Si})$-rich saponite in modern seafloor sites have been based on oxygen isotope thermometry, mineralogical association stability and direct measurement of fluid temperatures at vents, and mostly fall in the range $160-270{ }^{\circ} \mathrm{C}(\mathrm{Zi}-$ erenberg and Shanks 1988; Cole 1988; Percival and Ames 1993). High temperatures tend to favor Mg-rich compositions over Fe-rich ones (Zierenberg and Shanks 1988). Nonetheless, Mg-rich saponites formed at temperatures below ca. $150{ }^{\circ} \mathrm{C}$, usually in association with celadonite or celadonite-nontronite, are also found in the shallow ( $<700 \mathrm{~m}$ depth) hydrothermal alteration zone of oceanic basalts (Andrews 1980; Alt et al. 1986, 1998; Shau and Peacor 1992; Alt and Teagle 2003). The Mg-rich composition of these low- $T$ saponites is usually ascribed to partitioning of ferric iron into oxyhydroxides under seawater-dominated oxidizing conditions (Andrews 1980; Alt et al. 1986). Compared to higher- $T$ counterparts, these saponites are characterized by highly variable and, usually, higher $\mathrm{Al}_{2} \mathrm{O}_{3}$ contents (up to $12.0 \mathrm{wt} \%)$ and interlayer charge $(2 \mathrm{Ca}+\mathrm{Na}+\mathrm{K}=0.04$ 1.39 atoms per 22 oxygens), and are therefore mostly distinct from the saponites studied here (Fig. 10).

Saponite replacing olivine has higher $\mathrm{Si}$ and $\mathrm{Mg}$, and lower $\mathrm{Al}, \mathrm{Fe}, \mathrm{Ca}, \mathrm{K}$ and $\mathrm{Na}$ contents than that replacing plagioclase, and the latter typically has $\mathrm{Na}>\mathrm{Ca}>\mathrm{K}$ (cf analyses reported in Andrews 1980 and in Table 3 herewith). Some of our olivine-replacing saponites (Iv36.0) resemble low- $T$, low-Al olivine-replacing saponites from the oceanic crust of the Izu-Bonin forearc (cf. Alt et al. 1998). In both cases, partitioning of iron into oxide minerals (magnetite and Fe-oxyhydroxides, respectively) and the low contents of $\mathrm{Al}, \mathrm{Ca}$, and alkalis in the replaced mineral may account for the particular compositions of these saponites. Partitioning of iron into sulfides may account for the Mg-rich composition of ore-associated saponites from Ivanovka, although a relatively high temperature or a significant seawater 
component in the hydrothermal fluid may as well have played an important role.

Talc

Main modes of occurrence of talc in modern submarine hydrothermal fields include (i) massive terraces and ledges of ferroan talc associated with pyrrhotite and smectite (Guaymas Basin, Lonsdale et al. 1980); (ii) talc intergrown with saponite as replacement of olivine phenocrysts in high- $T$ alteration zones (in association with Fe-oxides and sulfides; hole 504B, Shau and Peacor 1992) and in seafloor altered hyaloclastites representing shallow hydrothermal upflow zones (Sea Cliff, Zierenberg et al. 1995); (iii) talc in pyrrhotite-rich hydrothermal mounds (Guaymas Basin, Koski et al. 1985; Middle Valley, Goodfellow and Franklin 1993) and in polymetallic sulfide chimneys (East Pacific Rise; e.g. Styrt et al. 1981); talc in epigenetic veins associated with anhydrite, $\mathrm{Mg}$-rich saponite, chlorite and sulfides (Atlantis II Deep; Zierenberg and Shanks 1983). According to Evans and Guggenheim (1988), talc in hydrothermal deposits can form by rapid mixing of hot, silica-saturated hydrothermal fluids with cold $\mathrm{Mg}$-rich bottom waters or pore fluids, and is often definitely more iron-rich than talc in metamorphosed ultramafic rocks and siliceous dolostones. Reported $\mathrm{FeO}$ contents are in the range 1-19 wt\% (e.g. McLeod and Stanton 1984; Aggarwal and Nesbitt 1984; Costa et al. 1983; Koski et al. 1985; Kranidiotis and MacLean 1987; Lonsdale et al. 1980; Shau and Peacor 1992; Goodfellow and Franklin 1993; Zierenberg et al. 1995) and distinct populations characterized by either moderately $(\mathrm{FeO} \leq 4 \mathrm{wt} \%)$ or highly ferroan compositions may occur at the same site. Available estimates of the temperatures of formation of hydrothermal talc are in the range $270-420{ }^{\circ} \mathrm{C}$ (Lonsdale et al. 1980; Koski et al. 1985; Styrt et al. 1981; Zierenberg and Shanks 1983), therefore usually higher than those reported for Mg-rich saponite.

The compositions of talc in Ivanovka rocks (Table 4) show highly variable $\mathrm{FeO}$ contents $(1.5-14.3 \mathrm{wt} \%)$ and are therefore comparable with those of typical hydrothermal talcs. Talc in sulfide-rich samples shows the largest compositional variability $(\mathrm{FeO}=3.2-14.3 \mathrm{wt} \%)$, even at the thin section scale, probably reflecting the interplay of several factors such as protolith bulk chemistry, hydrothermal conditions, partitioning of iron in sulfides, and kinetic constraints.

\section{Oxygen isotope thermometry}

Preliminary oxygen isotopic data on seven samples from the Ivanovka ore-field (six from drill-core DDH2T and one from a nearby outcrop of altered pillow-lavas) are displayed in Table 8 . The analyzed samples are representative of different alteration styles and include a serpentine-dominated altered melagabbroid (Iv33.6; cf. sequences 1-4 in Table 1), three talc-rich hydrothermal rocks (Iv93.0, Iv113.5, Iv176.2), two chloritites (Iv166.2, Iv209) and a chloritite showing further partial alteration to Mg-rich saponite (Iv136.0; cf. sequence 5 in Table 1). Temperatures were calculated for each sample assuming hydrothermal fluid-rock interactions have proceeded to equilibrium at high fluid/rock ratios and using mineralwater oxygen fractionation coefficients taken from sources listed in Table 8. The oxygen isotopic composition of the hydrothermal fluid was assumed to be that of Devonian seawater (estimated at -3 to $-1 \%$; Lécuyer and Allemand 1999).

The chloritites show low $\delta^{18} \mathrm{O}$ values $(-1.3$ to $+1.3 \%$ and yield relatively high temperature estimates (192-239 ${ }^{\circ} \mathrm{C}$ or $235-340{ }^{\circ} \mathrm{C}$, depending on the assumed fluid composition). The lowest of these temperatures refer to the saponite-altered chloritite, consistent with the relatively low temperature of formation of saponite in seafloor hydrothermal systems $\left(\leq 270{ }^{\circ} \mathrm{C}\right.$; Zierenberg and Shanks 1988; Cole 1988; Percival and Ames 1993; Andrews 1980; Alt et al. 1986, 1998; Shau and Peacor 1992; Alt and Teagle 2003). The measured oxygen isotopic composition of this sample may correspond to a two-component mixture of high- $T$ chlorite and low$T$ saponite.

Talc-rich samples and the talc separate from stockwork zones show high $\delta^{18} \mathrm{O}$ values $(+6.1$ to $+8.3 \%$ o and yield relatively low temperature estimates (121$154{ }^{\circ} \mathrm{C}$ or $146-182^{\circ} \mathrm{C}$ ). These temperatures are unusually low for hydrothermal talc (Lonsdale et al. 1980; Koski et al. 1985; Styrt et al. 1981; Zierenberg and Shanks 1983) and lower than those estimated for chloritites sampled at comparable depths. A possible explanation is that talc-rich rocks equilibrated with an ${ }^{18} \mathrm{O}$-enriched hydrothermal fluid, e.g. a fluid carrying a significant fraction of magmatic water $\left(\delta^{18} \mathrm{O}=+5\right.$ to $+6 \%$; Green et al. 1983), in which case the above temperatures could be significantly underestimated. Alternatively, the low temperatures may reflect late isotopic re-equilibration with colder fluids, possibly owing to mixing with cold recharge seawater circulating through the breccias. The inferred re-equilibration must have been less effective in the chloritites, possibly due to a lower reactivity of chlorite compared to talc.

The altered melagabbroid shows low $\delta^{18} \mathrm{O}(+0.1 \%)$ and yields intermediate temperature values (187$244^{\circ} \mathrm{C}$ ), compatible with the presence of saponite in the mineral assemblage.

\section{Discussion and conclusions}

The mafic-ultramafic-hosted massive-sulfide deposit of Ivanovka shows several analogies with certain deposits in modern seafloor-subseafloor hydrothermal settings. Similarities involve the occurrence of (i) hydrothermal phyllosilicate-bearing mineral assemblages consisting of different proportions of variably ferroan talc, $(\mathrm{Mg}$, 
$\mathrm{Si}$ )-rich and (Ca, Na, K)-poor saponite (stevensite), magnesian chlorite, quartz, carbonates, serpentine, and minor illite and, possibly, chlorite-smectite; (ii) hydrothermally-altered brecciated lithologies representing former tectonic breccias and/or olistostromes; (iii) a copper $(\mathrm{Co}, \mathrm{Au})$-bearing sulfide mineralization which is characterized by abundant tabular to lamellar pyrrhotite, locally forming peculiar, open-latticework aggregates typical of seafloor mounds. The third point will be the subject of a companion paper and will not further be addressed here. The first two points will be discussed through comparison with examples from modern oceanic hydrothermal sites.

\section{Hydrothermal conditions}

Zierenberg and Shanks (1988) and Cole (1988) showed that a decrease of temperature has a major influence on the composition of the hydrothermal phyllosilicate minerals, producing the sequence talc $\rightarrow$ Mg-saponite (stevensite) $\rightarrow$ Fe-rich saponite (nontronite). Studies on seafloor alteration of oceanic crust have also shown a general trend from smectites to chlorite-smectites to chlorite with increasing depth and temperature (see review in Alt 1995). On the other hand, geochemical modeling of hydrothermal systems predicts that Mg-rich saponite, talc and chlorite can coexist over a wide temperature interval under appropriate conditions (Zierenberg and Shanks 1983). Variations in rock/fluid ratios, $\mathrm{pH}$ and activities of chemical components in the rockfluid system can either expand or shrink the stability fields of the different alteration minerals. In our case, the lack of favorable mineral assemblages and of direct information on the chemical composition of the hydrothermal fluids precludes quantitative estimates of the physical conditions of phyllosilicate formation. Nonetheless, some general considerations on the hydrothermal conditions and on the nature of the hydrothermal fluids can still be drawn from the observed alteration patterns, taking into account the results of oxygen thermometry and preliminary whole-rock geochemical data (Nimis et al., in prep.).

Prevalence of chlorite in alteration assemblages after mafic, rather than ultramafic, protoliths and association of chlorite with any of talc, stevensite and serpentine indicates that availability of $\mathrm{Al}$ (mostly derived from alteration of plagioclase or glass) was the main limiting factor for chlorite stability. Extensive chloritization of mafic protoliths required significant leaching of silica, $\mathrm{Ca}$ and alkalis and addition of $\mathrm{Mg}$ and, possibly, Fe (Fig. 11). Apart from Fe, the intensity of these chemical transformations increased downward, presumably as a response to a thermal gradient. The observed large uptake of $\mathrm{Fe}$ in the analyzed samples is not correlated with depth and can be ascribed at least in part to the contribution of disseminated pyrrhotite. The uptake of $\mathrm{Mg}, \mathrm{Fe}$ and $\mathrm{S}$ to form the chlorite and the sulfide suggests that the mineralizing fluids were a

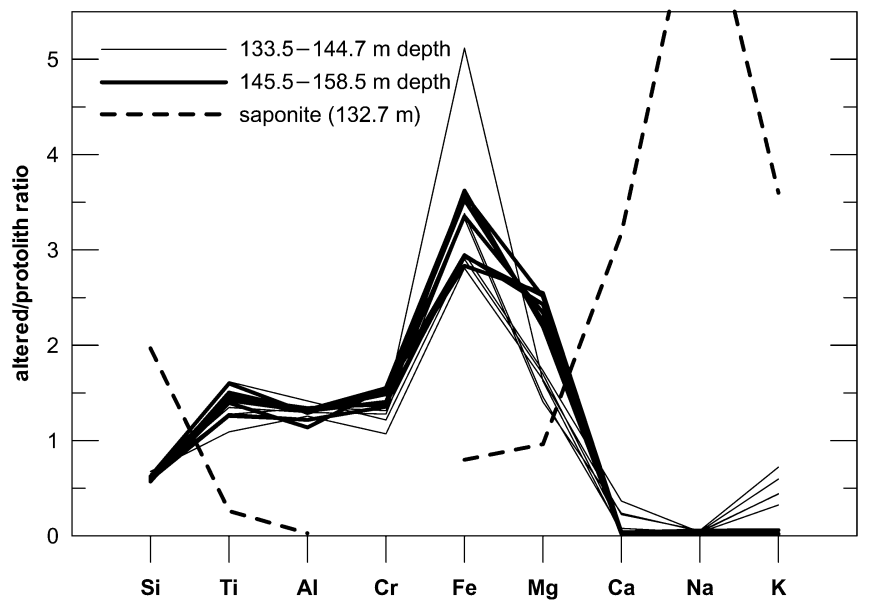

Fig. 11 Bulk rock chemical data for chloritites from Ivanovka drill-core DDH2T. Data are normalized to the compositions of least altered mafic rocks from surrounding areas, which were selected on the basis of strict geochemical affinities. Compared with the virtually immobile $\mathrm{Ti}, \mathrm{Al}$, and $\mathrm{Cr}$, the normalized compositions show a decrease in $\mathrm{Si}, \mathrm{Ca}$, and alkalis and an increase of $\mathrm{Mg}$ and Fe. Data are from Nimis et al. (in prep.). The dashed line shows the composition of a saponite partially replacing a chloritite clast, normalized to the composition of the host chlorite (cf. Tables 2 and 3 ). The saponite-forming reaction required addition of $\mathrm{Si}, \mathrm{Ca}$, and alkalis, and, possibly removal of Al. The apparent loss of Ti may reflect co-precipitation of rutile

mixture of seawater and reacted hydrothermal fluid. Similar conditions are believed to be dominant in diffuse upflow zones surrounding focused upflow zones beneath seafloor massive sulfide mounds or during initial alteration processes beneath the mounds (Alt 1995; Humphris et al. 1998).

Subsequent replacement of chlorite by stevensite in some mineralized chloritites (Fig. 5c, d) required addition of silica, $\mathrm{Ca}$ and alkali at virtually constant $\mathrm{Mg}$ and Fe (Fig. 11) and at probably lower temperature. Aluminum was either removed or retained, entirely or in part, in the residual chlorite. The apparent Ti depletion (Fig. 11) may be due to coprecipitation of accessory rutile. The formation of stevensite after chlorite was accompanied by crystallization in veins of further stevensite \pm talc, Mn-bearing dolomite-ankerite solid solutions and (Fe, Co, Ni)-sulfoarsenides (Fig. 5c, d), indicating a change from seawater-rich fluids to more highly reacted fluids enriched in silica, calcium and chalcophile elements. Vein minerals could precipitate by cooling and, perhaps, mixing of these hydrothermal fluids with recharge seawater. Aluminum removed during chlorite-to-stevensite transformation could eventually be reprecipitated in chlorite veins such as the late-stage chlorite-quartz-carbonate veins cutting through some massive pyrrhotite levels (Fig. 5h). Addition of silica, carbonates and sulfides was also involved in the transformation of serpentinites into talc-rich rocks at both shallower and deeper levels.

The above evolution is in broad agreement with the prograde sequence from a more seawater-influenced system to hydrothermal fluid-dominated that is com- 
monly observed in both ophiolites and modern seafloor examples (e.g. Zierenberg et al. 1995; Alt 1999, and references therein). The relatively high $\delta^{18} \mathrm{O}$ values of stevensite-altered chloritites and of talc-rich samples suggest that silicification/carbonatation occurred, or proceeded, at somewhat lower temperatures than chloritization.

\section{Geological setting}

The widespread chloritization of mafic protoliths at Ivanovka implies a significant contribution of $\mathrm{Mg}$-rich seawater to the hydrothermal fluid. Similar processes have been reported in both recharge zones and focused or diffuse upflow zones in modern and ancient seafloor hydrothermal systems (Alt 1995, and references therein) and are easily attained in highly permeable seafloor substrates. In particular, within substrates characterized by an abundance of unconsolidated tectonic breccias, fault talus, hyaloclastites, or detrital sediments, there is a potential for extensive subsurface mixing of ascending hot hydrothermal fluids with entrained cold seawater, and significant development of both subsurface sulfide mineralization and Mg-rich phyllosilicates (e.g. Zierenberg et al. 1993, 1995; Bach et al. 2002).

At Ivanovka, the occurrence of widespread clastic chromite within and above the main sulfide-bearing levels (Tesalina et al. 2003) and of pre-ore, polymictic mafic-ultramafic breccias throughout the ore-hosting rock sequence is evidence for the presence of abundant reworked, potentially unconsolidated material in the seafloor substrate at the time of hydrothermal deposition. Because of the extensive hydrothermal alteration and the small scale of the observations made on drillcore materials, the nature of the breccias, i.e. tectonic vs. sedimentary, remains unclear. Given the widespread occurrence of serpentinite-rich tectonic mélanges and olistostromes in surrounding areas (e.g. Seravkin et al. 2001), both modes of formation seem equally possible. Whatever their origin, the abundance of hydrothermally altered breccias is in line with the hypothesis of a highly permeable seafloor substrate at the time of hydrothermal circulation and of high seawater to hydrothermal fluid ratios at least during the early stages of the alteration process. Consistently, ore-host-rock relations and ore textures suggest that phyllosilicates and associated sulfides dominantly formed in the shallow subsurface. Like in some modern (e.g. Sea Cliff, Gorda Ridge, Zierenberg et al. 1995; Southwest Indian Ridge, Bach et al. 2002) and fossil analogues (e.g. Turner-Albright, Oregon, Zierenberg et al. 1988), only a minor part of the hydrothermal minerals probably formed on the palaeoseafloor by true exhalative mineralization.

The significant mineralogical and textural analogies designate the Ivanovka hydrothermal deposits as a close ancient analogue to certain mafic-ultramafic-hosted massive sulfide deposits found in modern oceanic settings. It is to be stressed, however, that although these analogies do suggest similar hydrothermal processes and conditions, they do not necessarily imply a similar geological scenery. In fact, in contrast with the ocean-ridge environments of the above-mentioned modern counterparts, the low-HFSE, possibly in part boninitic, affinity of the mafic protoliths and the high-Cr, low-Ti compositions of ore-hosted chromites (Nimis et al. 2003; Tesalina et al. 2003) indicate an early-arc or forearc setting as the most likely environment for the development of Ivanovka hydrothermalites. Such an environment would favor the development of near-surface tectonic activity, the formation of rough seafloor topography and the accumulation of abundant unconsolidated materials in the form of tectonic and sedimentary breccias, which could act as a highly permeable medium to hydrothermal fluid circulation.

Acknowledgements The authors are indebted to N. Tatarko (Bashkirgeologia, Ufa) for access to the Sibay lithotheque and drillcore DDH2T. J.-J. Orgeval (BRGM Orléans) and V. Zaykov (IMIN Miass) are thanked for help during the 2001 Urals field trip. B. Buschmann (Freiberg) is thanked for fruitful discussion. R. Carampin and L. Peruzzo (CNR-IGG Padova), E. Bechu (BRGM Orléans) and F. Zorzi (Padova) are thanked for assistance during EMP, SEM, XRD and oxygen isotope analyses. Reviews by J. Alt and an anonymous referee helped us to considerably improve the manuscript. This work was carried out in the framework of the EU-funded MinUrals project INCO COPERNICUS ICA2 CT2000-10011 (IMIN-Kroseven-BRGM Collaborative Partnership). P. Nimis and P. Omenetto gratefully acknowledge the financial support of the CNR-IGG (Padova) and Italian MURST ex $60 \%$ grants. S. Tesalina gratefully acknowledges the support of Russian Foundations RFFI No. 01-05-65329 and University of Russia.

\section{References}

Aggarwal PK, Nesbitt BE (1984) Geology and geochemistry of the Chu Chua massive sulfide deposit, British Columbia. Econ Geol 79:815-825

Alt JC (1995) Subseafloor processes in mid-ocean ridge hydrothermal systems. In: Seafloor hydrothermal systems: physical, chemical, biological, and geological interactions, Geophysical Monograph, vol 91. Am Geophys Un, pp 85-114

Alt JC (1999) Hydrothermal alteration and mineralization of oceanic crust: mineralogy, geochemistry, and processes. In: Barrie $\mathrm{T}$, Hannington $\mathrm{M}$ (eds) Volcanic associated massive sulfide deposits. Rev Econ Geol, vol 8. Soc Econ Geol, Chelsea, MI, pp $133-155$

Alt JC, Honnorez J, Laverne C, Emmermann R (1986) Hydrothermal alteration of a 1-km section through the upper oceanic crust, DSDP Hole 504B: the mineralogy, chemistry, and evolution of seawater-basalt interactions. J Geophys Res 91:1030910335

Alt JC, Laverne C, Muehlenbachs K (1985) Alteration of the upper oceanic crust: mineralogy and processes in Deep Sea Drilling Project Hole 504B, Leg 83. In: Anderson RN, Honnorez J, Becker K et al. (eds) Init Reports DSDP, vol 83. US Government Printing Office, Washington, DC, pp 217-247

Alt JC, Laverne C, Vanko, Tartarotti P, Teagle DAH, Bach W, Zuleger E, Erzinger J, Honnorez J, Pezard PA, Becker K, Salisbury MH, Wilkens RH (1996) Hydrothermal alteration of a section of upper oceanic crust in the eastern equatorial Pacific: a synthesis of results from Site 504B (DSDP legs 69, 70, and 83, and ODP legs 111, 137, 140, and 148). In: Alt JC, Kinoshita H, Stokking LB, Michael PJ (eds) Proc ODP Sci Res, vol. 148. College Station, TX (Ocean Drilling Program), pp $417-434$ 
Alt JC, Teagle DAH (2003) Hydrothermal alteration of upper oceanic crust formed at a fast-spreading ridge: mineral, chemical, and isotopic evidence from ODP Site 801. Chem Geol 201:191-211

Alt JC, Teagle DAH, Brewer T, Shanks WC III, Halliday A (1998) Alteration and mineralization of an oceanic forearc and the ophiolite-ocean crust analogy. J Geophys Res 103:1236512380

Alt JC, Zuleger E, Erzinger J (1995) Mineralogy and stable isotopic compositions of the hydrothermally altered lower sheeted dike complex, Hole 504B, Leg 140. In: Erzinger J, Becker K, Dick HJB, Stokking LB (eds) Proc ODP Sci Res, vol. 134/140. College Station, TX (Ocean Drilling Program), pp 155-166

Andrews AJ (1980) Saponite and celadonite in Layer 2 Basalts, DSDP Leg 37. Contrib Mineral Petrol 73:323-340

Bach W, Banerjee NR, Dick HJB, Baker ET (2002) Discovery of ancient and active hydrothermal systems along the ultra-slow spreading Southwest Indian Ridge $10^{\circ}-16^{\circ} \mathrm{E}$. Geochem Geophys Geosyst 3, DOI 10.1029/2001GC000279

Bettison LA, Schiffman P (1988) Compositional and structural variations of phyllosilicates from the Point Sal Ophiolite, California. Am Mineral 73:62-76

Bettison-Varga I, Mackinnon I-DR, Schiffman P (1991) Integrated TEM, XRD and electron microprobe investigation mixed-layer chlorite-smectite from the Point Sal Ophiolite, California. J Metamorph Geol 9:697-710

Bevins RE, Robinson D, Rowbotham G (1991) Compositional variations in mafic phyllosilicates from regional low-grade metabasites and application of the chlorite geothermometer. J Metamorph Geol 9:711-721

Brown D, Spadea P (1999) Processes of forearc and accretionary complex formation during arc-continent collision in the Southern Ural Mountains. Geol 27:649-652

Buchkovskiy ES (1970) Sulphide mineralization connected with ultramafic intrusions of the Western part of Magnitogorskiy megasinform. Geology, Mineralogy and Geochemistry of South Urals Sulphide Deposits. Ufa Institute of Geology Publications (in Russian), Ufa, pp 114-135

Cathelineau M (1988) Cation site occupancy in chlorites and illites as a function of temperature. Clay Miner 23:471-485

Cathelineau M, Nieva D (1985) A chlorite solid solution geothermometer; the Los Azufres (Mexico) geothermal system. Contrib Mineral Petrol 91:235-244

Christofides G, Thimiatis G, Koroneos A, Sklavounos S, Eleftheriadis G (1994) Mineralogy and chemistry of Cr-chlorites associated with chromites from Vavdos and Vasilika ophiolite complexes (Chalkidiki, Macedonia, N. Greece). Chemie der Erde 54:151-166

Clayton RN, O'Neil JR, Mayeda TK (1972) Oxygen isotope exchange between quartz and water. J Geophys Res 77:3057-3067

Cole DR, Ripley EM (1999) Oxygen isotope fractionation between chlorite and water from 170 to $350{ }^{\circ} \mathrm{C}$ : a preliminary assessment based on partial exchange and fluid/rock experiments. Geochim Cosmochim Acta 63:449-457

Cole TG (1988) The nature and origin of smectite in the Atlantis II Deep, Red Sea. Can Mineral 26:755-763

Costa UR, Barnett RL, Kerrich R (1983) The Mattagami Lake Archean $\mathrm{Zn}-\mathrm{Cu}$ sulfide deposit, Quebec: hydrothermal coprecipitation of talc and sulfides in a sea-floor brine pool-Evidence from geochemistry, ${ }^{18} \mathrm{O} /{ }^{16} \mathrm{O}$, and mineral chemistry. Econ Geol 78:1144-1203

De Caritat P, Hutcheon I, Walshe JL (1993) Chlorite geothermometry: a review. Clays Clay Miner 41:219-239

Escande M, Decarreau A, Labeyrie L (1984) Etude experimentale de l'exchangeabilité des isotopes de l'oxygene des smectites. C R Acad Sci Paris 299:707-710

Evans BW, Guggenheim S (1988) Talc, pyrophyllite, and related minerals. In: Bailey SW (ed) Hydrous phyllosilicates (exclusive of micas), Rev Mineral 19:225-294

Fouillac AM, Girard JP (1996) Laser oxygen isotope analysis of silicate/oxide grain separates: evidence for a grain size effect? Chem Geol 130:31-54
Goodfellow WD, Franklin JM (1993) Geology, mineralogy, and chemistry of sediment-hosted clastic massive sulfides in shallow cores, Middle Valley, northern Juan de Fuca Ridge. Econ Geol 88:2037-2068

Green GR, Ohmoto H, Date J, Takahashi T (1983) Whole-rock oxygen isotope distribution in the Fukazawa-Kosaka area, Hokuroku District, Japan, and its potential application to mineral exploration. In: Ohmoto $\mathrm{H}$, Skinner BJ (eds) The Kuroko and related volcanogenic massive sulfide deposits. Econ Geol Monogr 5:395-411

Herrington RJ, Armstrong RN, Zaykov VV, Maslennikov VV, Tesalina SG, Orgeval J-J, Taylor RN (2002) Massive sulfide deposits in the South Urals: geological setting within the framework of the Uralide Orogen. In: Brown D, Juhlin C, Puchkov (eds) Mountain building in the Uralides. AGU Geophys Monograph 132:155-182

Hey MH (1954) A new review of the chlorites. Mineral Mag 30:277-292

Humphris SE, Alt JC, Teagle DAH, Honnorez JJ (1998) Geochemical changes during hydrothermal alteration of basement in the stockwork beneath the active TAG hydrothermal mound. In: Herzig PM, Humphris SE, Miller DJ, Zierenberg RA (eds) Proc ODP Sci Res, vol 158. College Station, TX (Ocean Drilling Program), pp 255-276

Humphris SE, Herzig PM, Miller DJ, Alt JC, Becker K, Brown D, Brügmann $G$, Chiba $H$, Fouqet $Y$, Gemmell JB, Guerin $G$, Hannington MD, Holm NG, Honnorez JJ, Iturrino GJ, Knott R, Ludwig R, Nakamura K, Petersen S, Reysenbach A-L, Rona PA, Smith S, Sturz AA, Tivey MK, Zhao X (1995) The internal structure of an active sea-floor massive sulphide deposit. Nature 377:713-716

Humphris SE, Thompson G (1978) Hydrothermal alteration of oceanic basalts by seawater. Geochim Cosmochim Acta 42:107125

Ismagilov MI (1962) Some mineralogical and genetic characteristics of the Dergamish $\mathrm{Cu}-\mathrm{Co}$ deposit. Geology and mineralogy of copper deposits in Southern Urals (Geologo-mineralogicheskie osobennosti mednorudnykh mestorozhdenii Yuzhnogo Urala) (in Russian). Ufa Inst Geol Publ Ufa

Jiang WT, Peacor DR, Buseck PR (1994) Chlorite geothermometry? Contamination and apparent octahedral vacancies. Clays Clay Miner 42:593-605

Kim S-T, O’Neil JR (1997) Equilibrium and nonequilibrium oxygen isotope effects in synthetic carbonates. Geochim Cosmochim Acta 61:3461-3475

Koski RA, Lonsdale PF, Shanks WC, III, Berndt ME, Howe SS (1985) Mineralogy and geochemistry of a sediment-hosted hydrothermal sulfide deposit from the southern trough of Guaymas Basin, Gulf of California. J Geophys Res 90:66956707

Kranidiotis P, MacLean WH (1987) Systematics of chlorite alteration at the Phelps Dodge massive sulfide deposit, Matagami, Quebec. Econ Geol 82:1898-1911

Lackschewitz KS, Singer A, Botz R, Garbe-Schönberg D, Stoffers P, Horz K (2000) Formation and transformation of clay minerals in the hydrothermal deposits of Middle Valley, Juan de Fuca Ridge, ODP Leg 169. Econ Geol 95:361-390

Laird J (1988) Chlorites: metamorphic petrology. In: Bailey SW (ed) Hydrous phyllosilicates (exclusive of micas), Rev Mineral 19:405-453

Lapham DM (1958) Structural and chemical variation in chromium chlorite. Am Mineral 43:921-956

Le Maitre RW, Bateman P, Dudek A, Keller J, Lameyre J, Le Bas MJ, Sabine PA, Schmid R, Sorensen H, Streckeisen A, Woolley AR, Zanettin B (1989) A classification of igneous rocks and glossary of terms. Recommendation of the IUGS Subcommission on the Systematics of Igneous Rocks. Blackwell Scientific Publications, Oxford

Lécuyer C, Allemand P (1999) Modeling of the oxygen isotope evolution of seawater: implications for the climate interpretation of the $\delta^{18} \mathrm{O}$ of marine sediments. Geochim Cosmochim Acta 63:351-361 
Lonsdale PF, Bischoff JL, Burns VM, Kastner M, Sweeney RE (1980) A high-temperature hydrothermal deposit on the seabed at a Gulf of California spreading center. Earth Planet Sci Lett 49:8-20

Maslov AV, Cherkasov VL, Tishenko VT, Smirnova IA, Artyushkova OV, Pavlov VV (1993) Stratigraphy and correlation of Middle Paleozoic volcanogenic complexes of major copperpyrite districts of the South Urals (in Russian). Ufa Scientific Centre, RAS, Ufa, $217 \mathrm{pp}$

McLeod RL, Stanton RL (1984) Phyllosilicates and associated minerals in some Paleozoic stratiform sulfide deposits of southeastern Australia. Econ Geol 79:1-22

Melcher F, Grum W, Simon G, Thalhammer T, V, Stumpfl EF (1997) Petrogenesis of the ophiolitic giant chromite deposits of Kempirsai, Kazakhstan; a study of solid and fluid inclusions in chromite. J Petrol 38:1419-1458

Nimis P, Omenetto P, Tesalina SG, Zaykov VV, Tartarotti P, Orgeval J-J (2003) Peculiarities of some mafic-ultramafic-hosted massive sulfide deposits from southern Urals. A likely forearc occurrence. In: Eliopoulos DG et al. (eds) Mineral exploration and sustainable development, Proc 7th SGA Meeting, vol 1. Millpress, Rotterdam, pp 627-630

Percival JB, Ames DE (1993) Clay mineralogy of active hydrothermal chimneys and an associated mound, Middle Valley, northern Juan de Fuca Ridge. Can Mineral 31:957-971

Peter JM, Scott SD (1988) Mineralogy, composition, and fluidinclusion microthermometry of seafloor hydrothermal deposits in the southern trough of Guaymas Basin, Gulf of California. Can Mineral 26:567-587

Prokin VA, Buslaev FP (1999) Massive copper-zinc sulphide deposits in the Urals. Ore Geol Rev 14:1-69

Puchkov VN (1997) Structure and geodynamics of the Uralian orogen. In: Burg J-P, Ford M (eds) Orogeny through time. Geol Soc Spec Publ 121:201-236

Richards HG, Cann JR, Jensenius J (1989) Mineralogical zonation and metasomatism of the alteration pipes of Cyprus sulfide deposits. Econ Geol 84:91-115

Ridley WI, Perfit MR, Jonasson IR, Smith MF (1994) Hydrothermal alteration in oceanic ridge volcanics: a detailed study at the Galapagos fossil hydrothermal field. Geochim Cosmochim Acta 58:2477-2494

Rona PA (1988) Hydrothermal mineralization at oceanic ridges. Can Mineral 26:431-465

Saccoccia PJ, Seyfried WE (1994) The solubility of chlorite solid solution in $3.2 \mathrm{wt} \% \mathrm{NaCl}$ fluids from $300-400{ }^{\circ} \mathrm{C}, 500$ bars. Geochim Cosmochim Acta 58:567-585

Schiffman P, Staudigel H (1995). The smectite to chlorite transition in a fossil seamount hydrothermal system; the basement complex of La Palma, Canary Islands. J Metamorph Geol 13:487498

Seravkin IB, Znamenski SE, Kosarev AM (2001) Fault tectonics and ore deposits of the Trans-Uralian Bashkiria (in Russian). Poligrafcombinat, Ufa

Shau Y-H, Peacor DR (1992) Phyllosilicates in hydrothermally altered basalts from DSDP Hole 504B, Leg 83-a TEM and AEM study. Contrib Mineral Petrol 112:119-133

Shau Y-H, Peacor DR, Essene EJ (1990) Corrensite and mixedlayer chlorite/ corrensite in metabasalt from northern Taiwan; TEM/ AEM, EMPA, XRD, and optical studies. Contrib Mineral Petrol 105:123-142

Shikazono N, Kawahata H (1987) Compositional differences in chlorite from hydrothermally altered rocks and hydrothermal ore deposits. Can Mineral 25:465-474

Styrt MM, Brackmann AJ, Holland HD, Clark BC, Pisutha-Arnond V, Eldridge CS, Ohmoto H (1981) The mineralogy and the isotopic composition of sulfur in hydrothermal sulfide/sulfate deposits on the East Pacific Rise, $21^{\circ} \mathrm{N}$ latitude. Earth Planet Sci Lett 53:382-390
Tesalina SG, Nimis P, Augé T, Zaykov V (2003) Origin of chromite in mafic-ultramafic-hosted hydrothermal massive sulfides from the Main Uralian Fault, South Urals, Russia. Lithos 70:39-59

Tesalina SG, Zaykov VV, Orgeval J-J, Augé T, Omenetto P (2001) Mafic-ultramafic hosted massive sulphide deposits in Southern Urals (Russia). In: Piestrzynski et al. (eds) Mineral deposits at the beginning of the 21st century. Swets \& Zeitlinger Publishers, Lisse, pp 353-356

Turner RJW, Ames DE, Franklin JM, Goodfellow WD, Leitch CHB, Höy T (1993) Character of active hydrothermal mounds and nearby altered hemipelagic sediments in the hydrothermal areas of Middle Valley, northern Juan de Fuca Ridge; data on shallow cores. Can Mineral 31:973-995

Vanko DA, Laverne C, Tartarotti P, Alt JC (1996) Chemistry and origin of secondary minerals from the deep sheeted dikes cored during Leg 148 (Hole 504B). In: Alt JC, Kinoshita H, Stokking LB, Michael PJ (eds) Proc ODP Sci Res, vol. 148. College Station, TX (Ocean Drilling Program), pp 71-86

Xie X, Byerly GR, Ferrell REJ (1997) IIb trioctahedral chlorite from the Barberton greenstone belt; crystal structure and rock composition constraints with implications to geothermometry. Contrib Mineral Petrol 126:275-291

Zakharov AA, Zakharova AA (1975) The ore composition at the Ivanovka sulfide deposit in the Southern Urals versus their relation to specific lithology of host rocks. Geology and conditions of formation of copper deposits in the Southern Urals (Geologiya i Usloviya Obrazovaniya Mestorozhdenii Medi na Yuzhnom Urale) (in Russian). Ufa Institute of Geology Publications, Ufa, $105 \mathrm{pp}$

Zang W, Fyfe WS (1995) Chloritization of the hydrothermally altered bedrock at the Igarape Bahia gold deposit, Carajas, Brazil. Miner Deposita 30:30-38

Zaykov VV, Zaykova EV, Maslennikov VV (2000) Volcanic complexes and ore mineralization in spreading basins of the southern Urals. In: Mezhelovsk NV (ed) Geodynamics and metallogeny: theory and implications for applied geology. Ministry of Natural Resources of the RF and Geokart Ltd, Moscow, pp 315-337

Zheng Y-F (1993a) Calculation of oxygen isotope fractionation in anhydrous silicate minerals. Geochim Cosmochim Acta 57:1079-1091

Zheng Y-F (1993b) Calculation of oxygen isotope fractionation in hydroxyl-bearing silicates. Earth Planet Sci Lett 120:247-263

Zheng Y-F, Simon K (1991) Oxygen isotope fractionation in hematite and magnetite: a theoretical calculation and application to geothermometry of metamorphic iron-formation. Eur J Mineral 3:877-886

Zhong WJS, Hughes JM, Scotford DM (1985) The response of chlorite to metasomatic alteration in Appalachian ultramafic rocks. Can Mineral 23:443-446

Zierenberg RA, Koski RA, Morton JL, Bouse RM, Shanks WC, III (1993) Genesis of massive sulfide deposits on a sedimentcovered spreading center, Escanaba Trough, southern Gorda Ridge. Econ Geol 88:2069-2098

Zierenberg RA, Schiffman P, Jonasson IR, Tosdal RM, Pickthorn WJ, McClain JS (1995) Alteration of basalt hyaloclastite at the off-axis Sea Cliff hydrothermal field, Gorda Ridge. Chem Geol 126:77-99

Zierenberg RA, Shanks WC III (1983) Mineralogy and geochemistry of epigenetic features in metalliferous sediment, Atlantis II Deep, Red Sea. Econ Geol 78:57-72

Zierenberg RA, Shanks WC III (1988) Isotopic studies of epigenetic features in metalliferous sediment, Atlantis II Deep, Red Sea. Can Mineral 26:737-753

Zierenberg RA, Shanks WC III, Seyfried WE Jr, Koski RA, Strickler MD (1988) Mineralization, alteration, and hydrothermal metamorphism of the ophiolite-hosted Turner-Albright sulfide deposit, southwestern Oregon. J Geophys Res 93:4657-4674 